Article

\title{
The Uncertain Role of Biogenic VOC for Boundary-Layer Ozone Concentration: Example Investigation of Emissions from Two Forest Types with a Box Model
}

\author{
Boris Bonn ${ }^{1, *}$, Jürgen Kreuzwieser ${ }^{1}$, Felicitas Sander ${ }^{2}$, Rasoul Yousefpour ${ }^{2}$, Tommaso Baggio ${ }^{3}$ \\ and Oladeinde Adewale ${ }^{4}$ \\ 1 Chair of Tree Physiology, Albert Ludwig University, Georges-Koehler-Allee 053, D-79110 Freiburg i.Br., \\ Germany; juergen.kreuzwieser@ctp.uni-freiburg.de \\ 2 Chair of Forestry Economics and Forest Planning, Albert Ludwig University, Tennenbacher Str. 4, \\ D-79106 Freiburg i. Br., Germany; Felcitas.Sander@posteo.de (F.S.); \\ rasoul.yousefpour@ife.uni-freiburg.de (R.Y.) \\ 3 Department of Land, Environment, Agriculture and Forestry, University of Padova, Agripolis, \\ Viale dell'Università 16, I-35020 Legnaro (PD), Italy; tbaggio93@gmail.com \\ 4 UMR LERFoB, AgroParisTech, INRA, 54000 Nancy, France; alabifavour365@gmail.com \\ * Correspondence: Boris.Bonn@ctp.uni-freiburg.de; Tel.: +49-761-203-8310
}

Received: 18 August 2017; Accepted: 28 September 2017; Published: 5 October 2017

\begin{abstract}
High levels of air pollution including ground level ozone significantly reduce humans' life expectancy and cause forest damage and decreased tree growth. The French Vosges and the German Black Forest are regions well-known for having the highest tropospheric ozone concentrations at remote forested sites in Central Europe. This box model study investigates the sensitivity of atmospheric chemistry calculations of derived ozone on differently resolved forest tree composition and volatile organic compound emissions. Representative conditions were chosen for the Upper Rhine area including the Alsatian Vosges/France and the Black Forest/Germany during summer. This study aims to answer the following question: What level of input detail for Alsace and Black Forest tree mixtures is required to accurately simulate ozone formation? While the French forest in Alsace-e.g., in the Vosges-emits isoprene to a substantially higher extent than the forest at the German site, total monoterpene emissions at the two sites are rather similar. However, the individual monoterpene structures, and therefore their reactivity, differs. This causes a higher ozone production rate for Vosges forest mixture conditions than for Black Forest tree mixtures at identical $\mathrm{NO}_{\mathrm{x}}$ levels, with the difference increasing with temperature. The difference in ozone formation is analyzed in detail and the short-comings of reduced descriptions are discussed. The outcome serves as a to-do-list to allow accurate future ozone predictions influenced by the climate adaptation of forests and the change in forest species composition.
\end{abstract}

Keywords: tropospheric ozone pollution; influence of tree mixture; forest; BVOC emissions

\section{Introduction}

Tropospheric air pollution is known to affect human health [1] and plant growth substantially [2-4]. Studies on the impact of ground level ozone on plants have demonstrated serious damage to the surface and cell structure of species, causing plant injury and death and, consequently, reduced economic bargain [5-7]. Because of several stresses herbivorous plants have adopted several defense mechanisms, which enable them to tolerate different stresses at different intensities, for example different temperatures or ozone levels [8]. One of these mechanisms seems to work by using the 
reactions of semi-volatile organic compounds with ozone [9,10]. It has been demonstrated for example that ozone forces the release of highly reactive sesquiterpenes [10], which has the effect of reducing ozone mixing ratios near the plant's surface [10]. As well as having a detoxification effect, biogenic volatile organic compounds (BVOCs) can act as a tool for plant communication, e.g., allowing other neighbouring plants to get prepared for a threat, for instance against herbivory attack or ozone [11].

Tropospheric ozone-in this context boundary layer or ground level ozone-is formed in a photolytic production cycle that includes nitrogen oxides $\left(\mathrm{NO}_{\mathrm{x}}=\mathrm{NO}+\mathrm{NO}_{2}\right)$, volatile organic compounds (VOCs), and radiation. Based on the photosynthesis of ozone, hydroxyl radicals $(\mathrm{OH})$ are formed that partially react with VOCs, yielding organic peroxy radicals $\left(\mathrm{RO}_{2}\right)$. These $\mathrm{RO}_{2}$ radicals partially react with $\mathrm{NO}$, forming $\mathrm{NO}_{2}$ and an alkoxy radical producing hydrogen peroxide $\left(\mathrm{HO}_{2}\right)$, which regains $\mathrm{OH}$ by reacting with $\mathrm{NO}$, yielding a second $\mathrm{NO}_{2}$ molecule. This cycle can occur 40-60 times until being terminated. Each $\mathrm{NO}_{2}$ molecule can be photolysed resulting in ozone production. Depending on the conditions, this tropospheric ozone production cycle can be limited by the availability of VOCs-i.e., typical urban conditions with high $\mathrm{NO}_{x}$ emissions-or by $\mathrm{NO}_{x}$-i.e., typical background conditions that are found in forests with a substantial amount of biogenic VOCs (BVOCs). The area of production addresses a horizontal range of several hundred metres to $30 \mathrm{~km}$ depending on wind speed and radiation, and is most intense at points of transition from VOC- to $\mathrm{NO}_{\mathrm{x}}$-limited regions.

In this area, sufficient $\mathrm{NO}_{\mathrm{x}}$ is still present and the BVOC level increases due to emissions, for example by the forest. The list of compounds that contribute to BVOCs is extensive, with isoprene $\left(\mathrm{C}_{5} \mathrm{H}_{8}\right)$ and monoterpenes $\left(\mathrm{C}_{10} \mathrm{H}_{15}\right)$ being the highest contributors by amount released and reactivity. The group of sesquiterpenes $\left(\mathrm{C}_{15} \mathrm{H}_{24}\right)$ is a much more reactive $\mathrm{BVOC}$ group, for which even smaller ambient concentrations are sufficient to cause similar effects as those caused by isoprene or the monoterpenes. While isoprene is a single compound with approximately 1900 oxidation reactions and 600 products [12] until it is oxidized to carbon dioxide $\left(\mathrm{CO}_{2}\right)$, the group of monoterpenes abbreviates a set of more than 900 differently structured species of an identical molar mass, but with different amounts of carbon-carbon double bonds and chemical reactivity ranging by four orders of magnitude for ozone and by two orders of magnitude for the hydroxyl radical $(\mathrm{OH})$. Including a single monoterpene in a detailed chemical scheme may add 1550 further reactions and 520 species [13], thus substantially increasing the number of calculations. $\mathrm{OH}$ is involved in the tropospheric ozone formation cycle $[14,15]$ and altering its concentration, as well as the amount of total VOCs, potentially causes a change in tropospheric ozone. Therefore, although they protect the emitting plant from surface ozone, the released BVOCs are expected to affect the tropospheric ozone production cycle $[16,17]$ and its strength for the areas downwind the site of emission [17]. As a consequence, both ozone precursor groups-i.e., $\mathrm{NO}_{\mathrm{x}}$ and $\mathrm{VOCs}$ - need to be considered in order to understand the effects and feedback processes for different climate conditions. This is being addressed by recent studies of trends in ozone in North America and Europe [18-20]. They indicate an opposite trend in ground level ozone concentrations in cities and remote locations. While ozone tends to increase in urban areas due to a reduction in $\mathrm{NO}_{x}$-i.e., the major sink of ozone in these areas-ozone was found to decrease moderately in rural areas, where ozone formation is $\mathrm{NO}_{\mathrm{x}}$ limited. The role of BVOCs is more complex because of the large number of compounds with different reactivities and chemical degradation [21].

Despite these important features, atmospheric chemical reaction schemes currently implemented in different model types and scales-i.e., box, regional, global or climate models-are minimized because of simulation capacities and limitations. Moreover, not all the chemical degradation reactions from oxidation initiation until increasing $\mathrm{CO}_{2}$ levels are known or agreed upon. Detailed chemical schemes, such as the Master Chemical Mechanism (MCM) version 3.3.1 of Leeds University [12,22], include isoprene, aromatic [23] and non-aromatic compounds [24], three exemplary monoterpenes (d-limonene, $\alpha$ - and $\beta$-pinene) and a single sesquiterpene ( $\beta$-caryophyllene) [25] with about 12,500 individual reactions in total including further organic and inorganic reactions. This is drastically reduced to 105-237 reactions and 46-80 species (50 stable and 30 intermediate species) for chemical algorithms such as CB05, MM5, RACM or RADM2 [26,27], which are commonly used not only by regional, global 
and climate models but also for air quality and pollution forecasts [28-30]. A reliable match between simulation and observation is therefore key for predicting health issues and ecosystem damage.

In this study, we focus on ground level-i.e., boundary layer-ozone as an atmospheric pollution marker and the influence of forest tree mixture-i.e., tree emissions of BVOCs. The Southwestern part of Germany-i.e., Black Forest-is well known for its topmost hourly averaged ozone pollution levels during the summer, which have exceeded $200 \mu \mathrm{g} / \mathrm{m}^{3}$-i.e., approx. 100 parts per billion by volume $\left(\mathrm{ppb}_{\mathrm{v}}\right)$ (measurement height: ca. $4 \mathrm{~m}$ a.s.l.) - several times. It is interesting that, despite temperature, humidity and radiation being quite similar, summertime ozone concentrations nearby in the Alsatian Vosges (France) - about 50-60 km west of Black Forest-are on average 28\% lower (Figure 1). Significant differences between the two locations are evident throughout the year. The high pollution level in the Black Forest is linked to nitrogen oxides advected from the major transport routes in the Upper Rhine valley - separating Alsace on the West and Baden-Württemberg on the East—and high concentrations of biogenic VOCs released by the forest ecosystem (primarily trees). Ozone favouring conditions are listed in Table 1, which provides the Pearson correlation coefficients of different parameters, with the amount of ozone observed during summer by a background reference station of the local Agency for Air Quality and Environment (LUBW) in the Southern part of the Black Forest ("Schwarzwald-Sued", Muenstertal, $47.8099^{\circ} \mathrm{N}, 7.7645^{\circ} \mathrm{E}$ - see Section 2.3 for more details). Nitrogen monoxide (NO) and dioxide $\left(\mathrm{NO}_{2}\right)$ were separated into two ranges-i.e., $\mathrm{NO}_{\mathrm{x}}$ limited and $\mathrm{VOC}$ limited ozone production. For the condition of interest, the limitation of summertime tropospheric ozone production changes at $\mathrm{NO}_{2}$ volume mixing ratios of about $3.5 \mathrm{ppb}_{\mathrm{v}}$. High global radiation and temperatures cause elevated ozone as they enhance biogenic VOC emissions. Additionally, semi-volatile species-such as VOCs previously bound to organic aerosol particles-are released to the gas-phase and contribute to the amount of total VOCs that support ozone formation. Ozone production in the area of interest is nitrogen dioxide $\left(\mathrm{NO}_{2}\right)$ limited and the more that is available the more ozone will be formed. $\mathrm{NO}$ acts differently, as notable concentrations will decrease ozone by way of a chemical reaction-especially during the night-but will also enhance production of $\mathrm{NO}_{2}$, which is used in ozone production during the day [15]. On the contrary, wind speed acts as a reductive, as less dilution of precursor gases occurs and so more time is available to locally produce ozone.

Ozone observations: Vosges and Black Forest in 2015

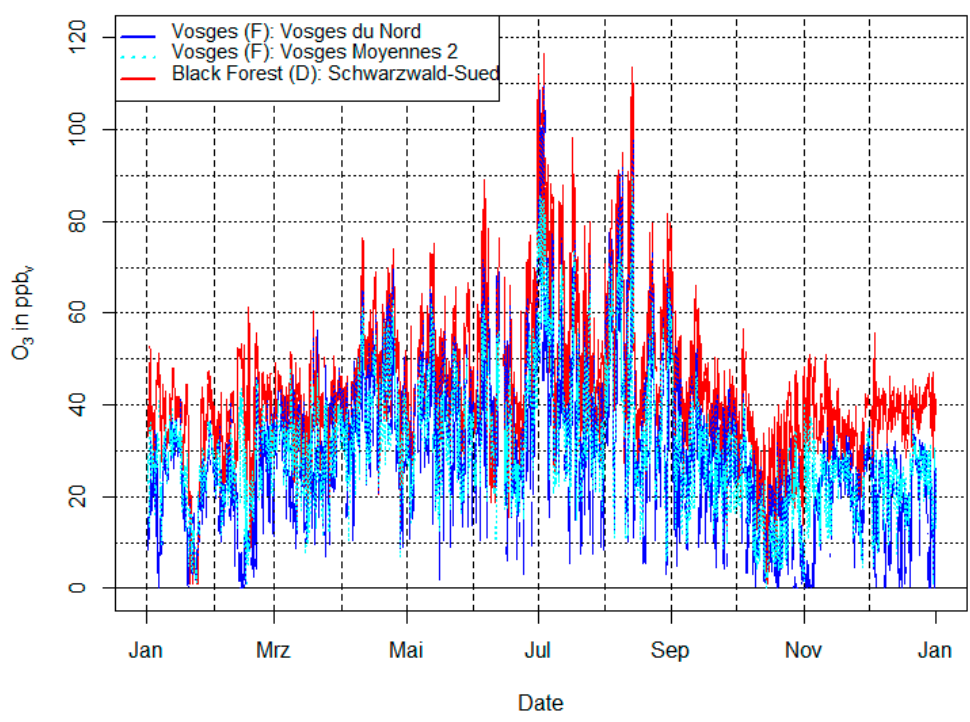

Figure 1. Hourly observations of background boundary layer atmospheric ozone volume mixing ratio values in the Alsatian Vosges ('Vosges du Nord' and 'Vosges Moyennes 2', courtesy of Pierre Robellet, l'Association pour la Surveillance et l'Etude de la Pollution Atmosphérique en Alsace (ALPA)) and the Black Forest ('Schwarzwald-Sued'), resolved by the local agencies for air quality. 
Because the focus of this study is on the influence of vegetation, we use $\mathrm{NO}$ and $\mathrm{NO}_{2}$ values from present observations but alter forest conditions. We consider two nearby differently composed ecosystems to investigate and analyse the resulting effects of ecosystem composition on BVOC emissions, resulting ozone mixing ratios, and formed secondary organic aerosols (SOA) in mass and number. Calculations are done using a box model, which considers forest properties and atmospheric chemistry: (a) at different temperatures; (b) at different ecosystem compositions (Alsace and the Black Forest); and (c) with and without considering SOA formation. For checking the sensitivity of the ozone calculations and predictions to the accurate description of individual processes, a comparison between observations (hourly resolved) and simulations during a period with low and high boundary layer ozone levels will be carried out in Section 3.1 (Figure 2). This will be used for demonstrating the interaction of local forests with air pollution and as the basis of a discussion about the need for further input to accurately predict ozone in the context of changing forest mixtures and climate change.

Table 1. Correlation coefficients $r$ (Pearson), $p$ values and number of data pairs $\mathrm{N}$ for different meteorological and atmospheric chemistry parameters with ground level ozone volume mixing ratios observed at Schwarzwald-Sued/Black Forest between June and August 2015.

\begin{tabular}{cccc}
\hline Parameter & $\mathbf{r}$ & $\boldsymbol{p}$ & $\mathbf{N}$ \\
\hline $\mathrm{T}$ & 0.78 & $<2.2 \times 10^{-16}$ & 2053 \\
\hline $\mathrm{NO}_{2}{ }^{*}$ & $0.19^{*}$ & $9.8 \times 10^{-13 *}$ & $1952^{*}$ \\
& $0.01^{* *}$ & $0.66^{* *}$ & 2036 \\
\hline global radiation & 0.11 & $2.1 \times 10^{-8}$ & 2053 \\
\hline $\mathrm{NO}$ & $0.01^{*}$ & $5.8 \times 10^{-9 *}$ & $1952^{*}$ \\
\hline wind speed & $-0.05^{* *}$ & $0.03^{* *}$ & $2036^{* *}$ \\
\hline wind direction & -0.09 & $1.6 \times 10^{-4}$ & 1756 \\
\hline
\end{tabular}

* denotes $\mathrm{NO}_{2}$ mixing ratios below $3.5 \mathrm{ppb}_{\mathrm{v}}$; ${ }^{* *}$ all $\mathrm{NO}_{2}$ measurements $\left(0-10 \mathrm{ppb}_{\mathrm{v}}\right)$. Values within the detection limits of the instruments are excluded.

\section{Materials and Methods}

\subsection{Box Model}

In this study, the CAABA box model [31], extended by biogenic VOC emissions and SOA formation [32], was used to cover the full range of gas-phase chemical reactions and phase changes in detail. More information about those reactions and processes can be found elsewhere [12,13,22-25]. While the organic chemistry scheme is known for the initial reactions and products [33], some degradation reactions have been considered differently by different groups and schemes, resulting in a small level of uncertainty. Here we concentrate on the Master Chemical Mechanism by Leeds University in its latest version [12], which was obtained via the website http:// mcm.leeds.ac.uk/MCM, for process studies. This includes time development of selected trace gas observations-such as NO, $\mathrm{NO}_{2}, \mathrm{CO}$, non-methane hydrocarbons-and meteorology—temperature $\mathrm{T}$, relative humidity $(\mathrm{rH})$, global radiation (GR) and mixing layer height (MLH) - as input. It considers about 6700 primary, secondary and radical chemical species and about 17,000 chemical reactions in the gas-phase, of which 2237 are traced by the output. However, only a small number of VOC species are provided as input as far as they are available from earlier studies. With respect to biogenic VOCs, the emission rates of isoprene, monoterpenes and sesquiterpenes are calculated (see Section 2.3) and mixed in each time-step into the entire box volume. The description of SOA processes-formation and destruction-considers 174 relevant VOC species based on volatility and substantial production, and has been described elsewhere in more detail [32]. For each time-step, the individual partitioning coefficients $K_{\text {org,i }}[34$ ] have been estimated and the equilibrium partitioning between both phases was calculated, readjusting 
the amount of corresponding species between absorbed and volatile phases. In this context, the present ambient organic aerosol mass needed was derived by the total particulate mass observations with a cut-off diameter of 10 micrometres $\left(\mathrm{PM}_{10}\right)$ at Schauinsland [35]. The total $\mathrm{PM}_{10}$ was considered to consist of $40 \%$ organic material, which represents a typical monthly mean value for $\mathrm{PM}_{10}$ analysis for Schauinsland (in the Black Forest, Germany) [36]. The contribution of different forest species (see Section 2.2) was read in and the emissions of each species were treated individually and summed up before mixing into the box.

\subsection{Forest Inventories}

Forest inventories were considered for (a) the regions of Alsace [37] and (b) Baden-Wuerttemberg, based on the BWI inventory 2012 [38] (Table 2). To obtain the dry weight biomass per square metre, the stock volume of the tree species was multiplied by the density factor (basic specific gravity, $0.55 \mathrm{Mg} / \mathrm{m}^{3}$ for broadleaves and $0.45 \mathrm{Mg} / \mathrm{m}^{3}$ for conifers [39]). The values were then multiplied by the expansion factor (1.612 for broadleaves and 1.3 for conifers [40]) to obtain the above-ground biomass.

An overview of the species, the mean dry weight biomass per square metre, and the contribution of (a) Alsace including the Alsatian Vosges (France) and (b) the Black Forest (Baden-Wuerttemberg, Germany), is provided in Tables 2 and 3. While Norway spruce (Picea abies) represents the dominant tree type in the Black Forest, followed by silver fir (Abies alba) and European beech (Fagus sylvatica), the tree mixture is notably different in the Vosges. There, beech makes the highest contribution by area. Silver fir, Norway spruce, oak (Quercus spp.) and Scots pine (Pinus sylvestris) follow next, all with similar contributions between $6 \%$ and $22 \%$. In summary, the French Alsatian forest consists $67 \%: 33 \%$, the French Alsatian Vosges of about 50\% coniferous and 50\% deciduous trees and the Black Forest type tree mixture has a ratio of about $75 \%: 25 \%$, i.e., a notably higher coniferous contribution.

Table 2. Contribution of different tree species to regional forests in Alsace (F, larger area), Vosges (F, smaller area) and the Black Forest (D), related to forest area based on the latest inventories [37,38].

\begin{tabular}{ccccc}
\hline Tree Species (lat.) & Tree Species (engl.) & Alsace [\%] & Vosges [\%] & Black Forest [\%] \\
\hline Alnus spp. & Alder & $2.2^{\Delta}$ & $1.3^{\Delta}$ & $1.2^{*}$ \\
Fraxinus excelsior & European ash & $4.4^{\Delta}$ & $2.5^{\Delta}$ & $0 *^{*}$ \\
Fagus sylvatica & European beech & 23.5 & 22.7 & 15.3 \\
Betula spp. & Birch & $3.3^{\Delta}$ & $2.5^{\Delta}$ & $1.9^{*}$ \\
Robinia pseudoacacia & Black locust & $2.2^{\Delta}$ & $1.3^{\Delta}$ & 0 \\
Pseudotsuga & Douglas fir & - & - & 5.1 \\
menziesii & Hornbeam & $4.4^{\Delta}$ & $1.9 \Delta$ & $1.2^{*}$ \\
Carpinus betulus & European larch & - & - & 1 \\
Larix decidua & Lime & $3.3^{\Delta}$ & $1.9 \Delta$ & $1{ }^{*}$ \\
Tilia spp. & Maple & $4.4^{\Delta}$ & $2.5^{\Delta}$ & $1.2^{*}$ \\
Acer spp & Oak & 11.1 & 10.8 & 3.1 \\
Quercus spp. & Scots pine & 9.2 & 5.9 & 5 \\
Pinus sylvestris & Poplar & $2.2^{\Delta}$ & $1.3^{\Delta}$ & $1.2^{*}$ \\
Populus spp. & Silver fir & 10.2 & 22.4 & 18.5 \\
Abies alba & Norway spruce & 9.2 & 15.8 & 42.8 \\
Picea abies & Other broadleaves & $6.6^{\Delta}$ & $3.8^{\Delta}$ & \\
& Other conifers & n.s. & n.s. & 90.8 \\
\hline
\end{tabular}

* equally split due to a lumped group within the corresponding inventory; ${ }^{\Delta}$ based on a lumped group within the corresponding inventory and split taking expert knowledge into account (lumping done differently for different countries). n.s. = statistically not significant within the corresponding inventory.

\subsection{Emissions}

The hourly emissions $E_{X}$ per gram of dry weight biomass were considered for three different biogenic VOC species and classes, i.e., isoprene $\left(\mathrm{C}_{5} \mathrm{H}_{8}\right)$, monoterpenes $\left(\mathrm{C}_{10} \mathrm{H}_{16}\right)$ and sesquiterpenes 
$\left(\mathrm{C}_{15} \mathrm{H}_{24}\right)$. Isoprene and monoterpenes affect tropospheric ozone production and destruction [41-43] because of their notable atmospheric mixing ratios $\left(>100 \mathrm{ppt}_{\mathrm{v}}\right)$, while sesquiterpenes are less abundant (lowest ppt $_{\mathrm{v}}$ range) and only act reductive on surface ozone predominantly in the direct vicinity of emission sites. Isoprene and monoterpenes were therefore included in the tropospheric chemistry simulations, while sesquiterpenes were considered for new particle formation calculations only. Each individual BVOC emission rate $E_{X}$ was described in terms of its dependency on leaf or needle temperature [44] $\left(\gamma_{\mathrm{T}}\right)$ and photosynthetic active radiation $\left(\gamma_{\mathrm{P}}\right)$ in accordance with references [45,46], as far as direct measurement data or literature were available.

$$
E_{X}=E_{X_{i}} \times \gamma_{P} \times \gamma_{T} \times \gamma_{d r} \times \gamma_{a}
$$

The potential interference of drought and ageing factors had to be ignored $\left(\gamma_{\mathrm{dr}}=\gamma_{\mathrm{a}}=1\right)$ because of insufficient information on individual species and these therefore require future investigation. The details of tree species' specific basal emission rates $E_{X_{i}}$ at $30^{\circ} \mathrm{C}$, temperature dependencies and dry weight biomasses are summarized in Tables 3 and S1 (sesquiterpenes). Because of strong isoprene emitters such as oak among the Alsatian Vosges forest trees, the basal isoprene emission rate $\mathrm{E}_{0 \text {,isop }}$ at $30^{\circ} \mathrm{C}$ and $1000 \mu \mathrm{mol} / \mathrm{m}^{2} / \mathrm{s}$ is about ten times more than that of the German Black Forest (18.3 to $1.9 \mu \mathrm{g} / \mathrm{g}(\mathrm{dw}) / \mathrm{h}$, respectively). Thus, under identical meteorological conditions, isoprene emissions are remarkably higher in the Vosges (Alsace).

Monoterpene emissions were calculated as a mixture of de novo and pool emissions of the 16 different tree types considered. The sum of emitted monoterpenes was split according to their structure-i.e., endo- and exo-cyclic for each tree species according to the literature-and were treated as $\alpha$ - (endocyclic) and $\beta$-pinene (exocyclic) in the following.

At first glance, the monoterpene emissions of the Black Forest under standard conditions are less different to those of the Vosges than are the isoprene emissions. The forests in the Alsatian Vosges release only about $30 \%$ more than the Black Forest species under standard conditions. As a consequence, the French forest represents a substantially higher BVOC source than the nearby German forest, with resulting effects on tropospheric ozone production.

The estimate of total emission rates $\Sigma E_{X}(i)$ and the transfer to ambient concentrations of compound $X[X]$ included several steps (Equation (1)): (i) summing the individual contributions by tree species weighted by relative contribution to forest area; (ii) multiplication with escaping fraction and (iii) distribution into the meteorological boundary layer height (MLH) (see Section 2.5 below).

$$
[\mathrm{X}]=[\mathrm{X}]_{0}+\Sigma\left(\mathrm{E}_{\mathrm{X}}(\mathrm{i}) \times \mathrm{g}(\mathrm{dw})_{\mathrm{i}}\right) \times \text { survival } / \mathrm{MLH} / \mathrm{M}_{\mathrm{wx}} \times \Delta \mathrm{t} / 3600 \mathrm{~s} \times 10^{-12} \times \mathrm{N}_{\mathrm{A}}
$$

$[X]_{0}$ is the resulting concentration of the final time-step before adding the emission; $g(d w)_{i}$ is the individual dry weight biomass of a tree species; $\mathrm{M}_{\mathrm{wx}}$ is the molar weight of the BVOC (such as $68 \mathrm{~g} /$ mole for isoprene); $\Delta \mathrm{t}$ is the calculated model time-step; and $\mathrm{N}_{\mathrm{A}}$ represents the Avogadro constant of $6.022 \times 10^{23}$ molecules/mole. Survival comprises the amount of BVOC escaping the canopy into the open atmosphere that is accessible to photochemistry:

$$
\text { Survival }=1-\mathrm{CH} /\left(0.3 \times \mathrm{u} \times /\left(\mathrm{k}_{\mathrm{O} 3}{ }^{\mathrm{BVOC}} \times\left[\mathrm{O}_{3}\right]+\mathrm{k}_{\mathrm{OH}}{ }^{\mathrm{BVOC}} \times[\mathrm{OH}]+\mathrm{k}_{\mathrm{NO}^{3}}{ }^{\mathrm{BVOC}} \times\left[\mathrm{NO}_{3}\right]\right)+\mathrm{CH}\right)
$$

As a first estimate, the crown height $(\mathrm{CH})$ was set to $10 \mathrm{~m}$ for all the species included, because of the lack of further detailed information. The mean tree height was assumed to be $25 \mathrm{~m}$. 
Table 3. Assumed mean dry weight biomass (DWB), basal emission factors $\mathrm{E}_{0}$ for isoprene and monoterpenes (MT) at $30{ }^{\circ} \mathrm{C}$ and temperature coefficients $\beta_{\mathrm{MT}}$ of the individual tree species considered ([46] and ref. therein). *DWB values are based on the Black Forest inventory (BWI 2012) [38].

\begin{tabular}{cccccc}
\hline Tree Species (lat.) & Tree Species (engl.) & DWB ${ }^{*}\left[\mathbf{g} / \mathbf{m}^{2}\right]$ & $\begin{array}{c}\mathbf{E}_{\mathbf{0}, \mathbf{i s o p}} \\
[\boldsymbol{\mu} \mathbf{g} \mathbf{d} \mathbf{d w}) / \mathbf{h}]\end{array}$ & $\begin{array}{c}\mathbf{E}_{\mathbf{0}, \mathbf{M T}} \\
{[\boldsymbol{\mu g} / \mathbf{g}(\mathbf{d w}) / \mathbf{h}]}\end{array}$ & $\boldsymbol{\beta}_{\mathbf{M T}}\left[\mathbf{K}^{-\mathbf{1}}\right]$ \\
\hline Alnus spp. & Alder & $109 \pm 96$ & 0.018 & 0.13 & 0.09 \\
Fraxinus excelsior & European ash & $139 \pm 116$ & 0.012 & 0.012 & 0.09 \\
Fagus sylvatica & European beech & $180 \pm 140$ & 0 & 43.5 & 0.31 \\
Betula spp. & Birch & $105 \pm 31$ & 0 & 6.7 & 0.09 \\
Robinia pseudoacacia & Black locust & $85 \pm 75$ & 11.9 & 3.34 & 0.09 \\
Pseudotsuga menziesii & Douglas fir & $141 \pm 45$ & 0.008 & 0.064 & 0.08 \\
Carpinus betulus & Hornbeam & $132 \pm 110$ & 0.1 & 0.0093 & 0.09 \\
Larix decidua & European larch & $125 \pm 91$ & 0.4 & 13.1 & 0.07 \\
Tilia spp. & Lime & $110 \pm 92$ & 5.5 & 0 & 0.09 \\
Acer spp & Maple & $132 \pm 110$ & 3.9 & 0 & 0.09 \\
Quercus spp. & Oak & $179 \pm 83$ & 20.4 & 13.1 & 0.121 \\
Pinus sylvestris & Scots pine & $77 \pm 39$ & 0 & 7.48 & 0.09 \\
Populus spp. & Poplar & $85 \pm 75$ & 76.3 & 3.45 & 0.09 \\
Abies alba & Silver fir & $174 \pm 54$ & 0.038 & 28.8 & 0.135 \\
Picea abies & Norway spruce & $177 \pm 31$ & 0.05 & 0.886 & 0.11 \\
\hline
\end{tabular}

\subsection{Secondary Organic Aerosol Treatment}

Based on the saturation vapour pressure and estimated ambient mixing ratios, the partitioning of 174 organic oxidation products of the most important anthropogenic and biogenic VOCs between gas- and particle-phases were treated explicitly. Saturation vapour pressures of the SOA species were calculated based on group contribution methods, splitting the corresponding molecules into functional groups for which a parameterization was derived from a series of similar structured compounds [47,48]. Corresponding saturation vapour pressures were used to obtain the individual partitioning coefficients as a function of temperature [34]. The essential amount of total organic particular mass $\mathrm{M}_{\text {org }}$ was derived from ambient $\mathrm{PM}_{10}$ measurements at Schauinsland (Black Forest, Germany, EMEP station DE0003R, $47.915^{\circ} \mathrm{N}, 7.909^{\circ} \mathrm{E}, 1205 \mathrm{~m}$ a.s.l.). From former studies, it can be assumed that the observed $\mathrm{PM}_{10}$ consist of approximately $40 \%$ organic compounds [35]. Subsequent iteration achieved the realistic partitioning equilibrium of individual species, depending on the individual saturation concentrations, the amount present, and the total mass of organic aerosols. Further details on the basics and the procedure can be found elsewhere [32,33].

\subsection{Simulations}

Simulations are focused on two areas close by-i.e., the Alsatian Vosges in Eastern France and the Black Forest in the Southwestern part of Germany. Both areas are covered by substantial amounts of forest, that are each different in their tree species composition. While the Upper Rhine valley is known as a major traffic and transportation route with substantial emissions of nitrogen oxide $\left(\mathrm{NO}_{\mathrm{x}}\right)$, observations within the Black Forest display Germany's uppermost ground level ozone pollution levels. This is suspected to be caused by the transport of $\mathrm{NO}_{\mathrm{x}}$ from the Upper Rhine valley towards the Black Forest that then mixes with BVOC emissions from the forest. Thus, the effect of forest tree species' composition on tropospheric ozone production and mixing ratio is expected to be both most sensitive and most likely.

In order to investigate this, exemplary box model simulations were performed for observed meteorological and atmospheric chemistry conditions for June, July and August 2015. The focus was set on the first two weeks in August, which covered the highest annual temperature $\left(34.0 \pm 0.1^{\circ} \mathrm{C}\right)$ and GR $\left(920 \pm 1 \mathrm{~W} / \mathrm{m}^{2}\right)$, with maximum surface ozone $\left(113.6 \pm 0.2 \mathrm{ppb}_{\mathrm{v}}\right)$ and notable $\mathrm{PM}_{10}\left(18 \pm 1 \mu \mathrm{g} / \mathrm{m}^{3}\right)$ values, especially for remote areas. The observation site "Schwarzwald-Sued" of LUBW at Muenstertal $\left(47.8099^{\circ} \mathrm{N}, 7.7645^{\circ} \mathrm{E}, 902 \mathrm{~m}\right.$ a.s.l.) was picked as the reference station. It is located in the upper part of the Black Forest in Southwestern Germany at $902 \mathrm{~m}$ a.s.l., is classified as remote, and is surrounded 
by mixed forest. Surface ozone observations display the highest ozone level of this area and are assumed to be representative for the Black forest area. The following parameters were monitored at this site, provided in 30-minute time resolution, and were used for the simulation: Temperature, dew point, atmospheric pressure, $\mathrm{GR}, \mathrm{NO}$, and $\mathrm{NO}_{2}$. Surface ozone measurements were used only for comparison and as a starting value at time 0 . Several parameters were set to be constant due to no direct measurements and thus no information about a daily pattern. Those parameters and their corresponding values were derived from earlier studies [49-51] or they were assumed based on current mean observations for remote locations: methane $\left(\mathrm{CH}_{4}\right)=1900 \mathrm{ppb}_{\mathrm{v}}$ and $\mathrm{CO}=100 \mathrm{ppb}_{\mathrm{v}}$.

The meteorological boundary (mixing) layer height MLH in metres was treated as:

$$
\begin{gathered}
\mathrm{MLH}=\max (10 .,(60 .+40 . \times \sin ((\text { hour-days }) \times 24-10) / 24 \times \pi \times 2)+1000 \times \\
\left.\left.\left.\exp (-0.035 \times((\text { hour-days }) \times 24-17))^{2}\right) \times(-270+75.7 \times(\mathrm{T}-273.15)) / 2400\right)\right) \times 2 .
\end{gathered}
$$

With a maximum of $1600 \mathrm{~m}$ at 2 p.m., which is in line with the heights observed by Kalthoff et al. [52], i.e., 1400 and $1900 \mathrm{~m}$ at 1:48 p.m. in June 1996. Photosynthetic active radiation (PAR), required for BVOC emission calculations, was scaled by global radiation measurements and assumed as:

$$
\text { PAR }=700 \mu \mathrm{mol} \mathrm{m}{ }^{-2} \mathrm{~s}^{-1} / 0.4 \times \mathrm{GR}(\text { measured }) / \mathrm{GR}(\text { daily maximum in summer) } .
$$

\section{Results}

\subsection{Match with Observations}

In order to check the reproducibility of observed ground level ozone mixing ratios by the box model, both observed and simulated ozone values were compared for June, July and August-i.e., the time of highest annual ozone mixing ratios in the meteorological boundary layer, at the reference site for the Black forest in Muenstertal. The results of an exemplary week at the beginning of August are displayed in Figure 2. Different sensitivity runs were conducted to find the best deposition velocity and minimum $\mathrm{NO}_{2}$ mixing ratios for the best agreement between observations and simulation based on the range of published values.

With respect to ozone deposition velocity $\left(\mathrm{v}_{\mathrm{dep}}\right)$, the value is influenced by the structure of the section of forest that the air mass had crossed before arrival. Predominantly coniferous forests result in a very small deposition rate, while deciduous forests cause about twice to three times the value (Figure 2, left). A mixed-to-coniferous forest structure was found to match best and a $\mathrm{v}_{\text {dep }}$ value of $0.1 \mathrm{~cm} / \mathrm{s}$ was chosen in the following. With respect to the minimum value of nitrogen dioxide (limiting factor), different simulations between one and five ppb were performed during the daytime (Figure 2, right). This concluded in an overall match between observed and simulated ground level ozone with a correlation coefficient of 0.81 for a daytime minimum $\mathrm{NO}_{2}$ mixing ratio of $3.5 \mathrm{ppb}_{\mathrm{v}}$ and a night time minimum $0.5 \mathrm{ppb}_{\mathrm{v}}$. Both different minimum values of $\mathrm{NO}_{2}$ are crucial as $\mathrm{NO}_{2}$ displays two different effects, i.e., a substantial sink for ozone during the night and an essential source for tropospheric ozone production during day $\left(\mathrm{NO}_{\mathrm{x}}\right.$ limited regime). The values are partially higher than observed, as the detected ozone is not necessarily formed on-site but during the air mass transport before arrival. This transport commonly originates in regions of elevated $\mathrm{NO}_{\mathrm{x}}$ (transport routes in the Upper Rhine valley and Freiburg) and during the crossing if the $\mathrm{NO}_{\mathrm{x}}$ in the Black Forest region gets vertically diluted and chemically converted during its travelling time. The described set-up was considered to be the best match and is treated as the reference for the following.

As Figure 2 indicates, the air chemistry box model results display generally a stronger daily variation than the observations. Differences between observation and simulations are apparent, especially during night. This is caused by changes in vertical mixing and changing slope currents for different times of the day, which is challenging to reproduce with a 0D-model. A highly resolved 3D model with sufficient boundary values and parameter distributions would be needed, which 
are currently lacking. Furthermore, different $\mathrm{NO}_{\mathrm{x}}$ mixing ratios will prevail during both day and night-i.e., smaller values during the night, where advection from anthropogenically-affected areas like the Upper Rhine valley is negligible, and higher values during the day, when vertical mixing and transport of $\mathrm{NO}_{\mathrm{x}}$ is notable. The effect is critical for ozone sink and production, as production in this remote area is evidently $\mathrm{NO}_{\mathrm{x}}$ limited (see e.g., correlation coefficient $\mathrm{r}$ of surface ozone with nitrogen dioxide in Table 1) and a lack of $\mathrm{NO}_{x}$ will result in reduced ozone production. This is supported by a moderate anti-correlation of daytime ground level ozone with monoterpenes $(\mathrm{r}=-0.16)$ and isoprene $(r=-0.09)$ for Black Forest simulations during the highest ozone periods in July and August 2015. As the box model is unable to simulate regional transport, the focus was on reproducing the daily and nightly maximum ground level ozone mixing ratios. $\mathrm{NO}_{\mathrm{x}}$ was therefore overestimated. SOA contributions to tropospheric ozone from advection-i.e., the evaporation of previously formed organic aerosol mass-are smaller if considered compared to the neglected $+(36 \pm 25) \%$.

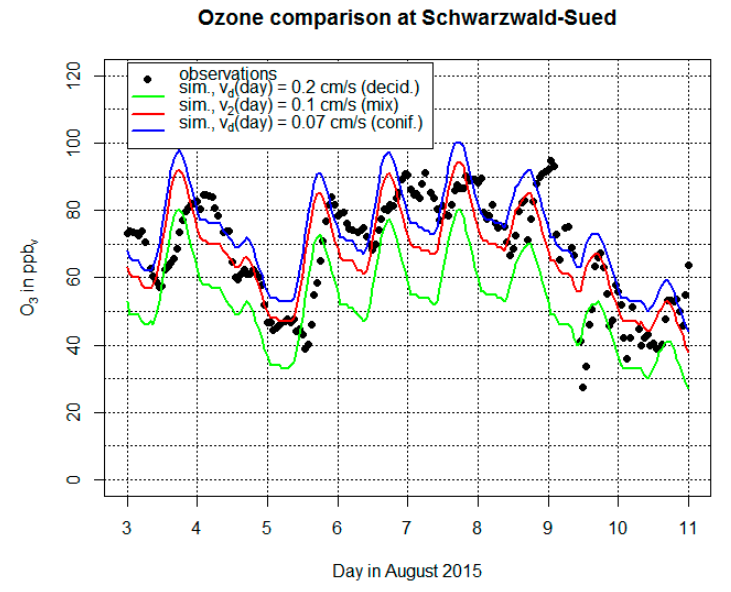

(a)

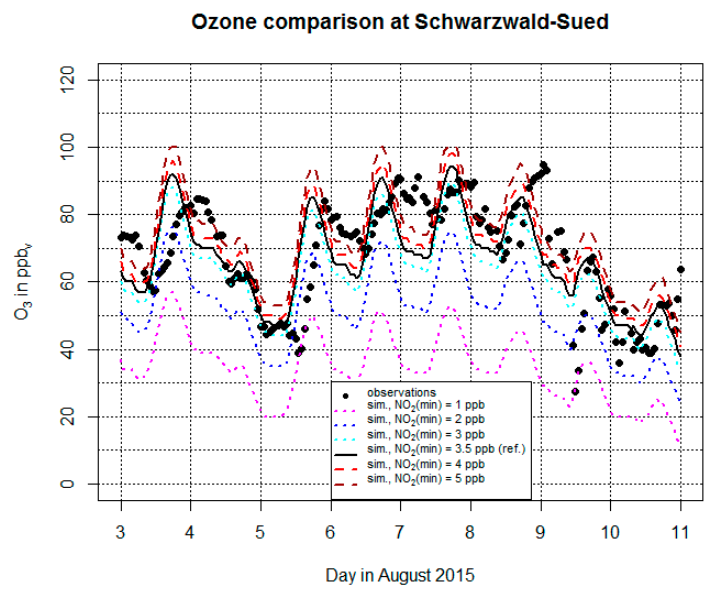

(b)

Figure 2. Comparison of observed and simulated ground level ozone volume mixing ratios at the remote reference site in the Black Forest. Dots display observed ozone values and lines display simulated ones. Different lines show the $\mathrm{NO}_{2}$ effect on ozone, relying on air mass history, which is unknown for the box model. (a) Sensitivity runs for different ozone deposition velocities; (b) Sensitivity for different minimum $\mathrm{NO}_{2}$ mixing ratios during the formation process.

\subsection{Effect of BVOCs}

While the link between tropospheric ozone formation and $\mathrm{NO}_{\mathrm{x}}$ in a $\mathrm{NO}_{\mathrm{x}}$ limited area is evident-i.e., the more $\mathrm{NO}_{x}$ the more ozone is formed - the situation with the VOCs depends on the amount present and the VOCs' reactivity with ozone, $\mathrm{OH}$ and $\mathrm{NO}_{3}$. In mid-latitude forests, ambient VOCs are predominantly of biogenic origin [14]. The most reactive ones are isoprene and terpenes (mono- and sesquiterpenes), with atmospheric lifetimes between seconds and several hours. Isoprene $\left(\mathrm{C}_{5} \mathrm{H}_{8}\right)$ and its reaction products contribute nearly exclusively to the gas-phase and gently force ozone production, but isoprene destroys ozone by direct reaction, resulting in a minor reduction (see right-hand column in Table 4). Monoterpenes act in a similar way, but react to a larger extent with ozone, bind hydroperoxy radicals $\left(\mathrm{HO}_{2}\right)$ into larger molecular structures. They slow down the ozone production cycle and form SOA mass yielding a stronger negative correlation. 
Table 4. Correlation coefficients $r$ of different atmospheric chemistry parameters with ozone simulated for both conditions, i.e., Vosges (Alsace) forest and Black Forest between June and August 2015.

\begin{tabular}{cccccc}
\hline Parameter & & r(Vosges) & p(Vosges) & r(Black Forest) & p(Black F.) \\
\hline $\mathrm{HO}_{2}$ & $\mathrm{O}_{3}$ & 0.39 & $<2.2 \times 10^{-16}$ & 0.39 & $<2.2 \times 10^{-16}$ \\
$\mathrm{OH}$ & $\mathrm{O}_{3}$ & 0.35 & $<2.2 \times 10^{-16}$ & 0.35 & $<2.2 \times 10^{-16}$ \\
Isoprene & $\mathrm{O}_{3}$ & -0.07 & $5.5 \times 10^{-8}$ & -0.07 & $4.1 \times 10^{-8}$ \\
Monoterpenes & $\mathrm{O}_{3}$ & -0.26 & $<2.2 \times 10^{-16}$ & -0.24 & $<2.2 \times 10^{-16}$ \\
$\mathrm{SOA}$ & $\mathrm{O}_{3}$ & -0.28 & $<2.2 \times 10^{-16}$ & -0.29 & $<2.2 \times 10^{-16}$ \\
Isoprene & $\mathrm{SOA}$ & -0.15 & $1.7 \times 10^{-11}$ & -0.11 & $1.5 \times 10^{-9}$ \\
Monoterpenes & $\mathrm{SOA}$ & -0.11 & $5.4 \times 10^{-6}$ & -0.09 & $4.1 \times 10^{-8}$ \\
$\mathrm{~T}$ & $\mathrm{SOA}$ & -0.46 & $<2.2 \times 10^{-16}$ & -0.46 & $<2.2 \times 10^{-16}$ \\
\hline
\end{tabular}

\subsection{Alsatian Vosges Forest vs. Black Forest: Effects of BVOC Mixtures}

Next, we investigate the impact of different vegetation structures-i.e., forest tree species-on surface ozone, and SOA levels at otherwise identical conditions-i.e., meteorology and inorganic compound concentrations. In order to do so, two neighbouring forested areas with similar meteorological conditions but different species relevance-i.e., the Vosges and the Black Forest-are used (see Table 2, Section 2.2). Because of the different emission rates, the Alsace type forests emit significantly more isoprene, while monoterpenes are released to a similar extent by both forest mixtures (Figure 3). The exact ratio of monoterpenes provided by the Alsatian Vosges forest type to Black forest type mixtures depends on temperature and PAR.
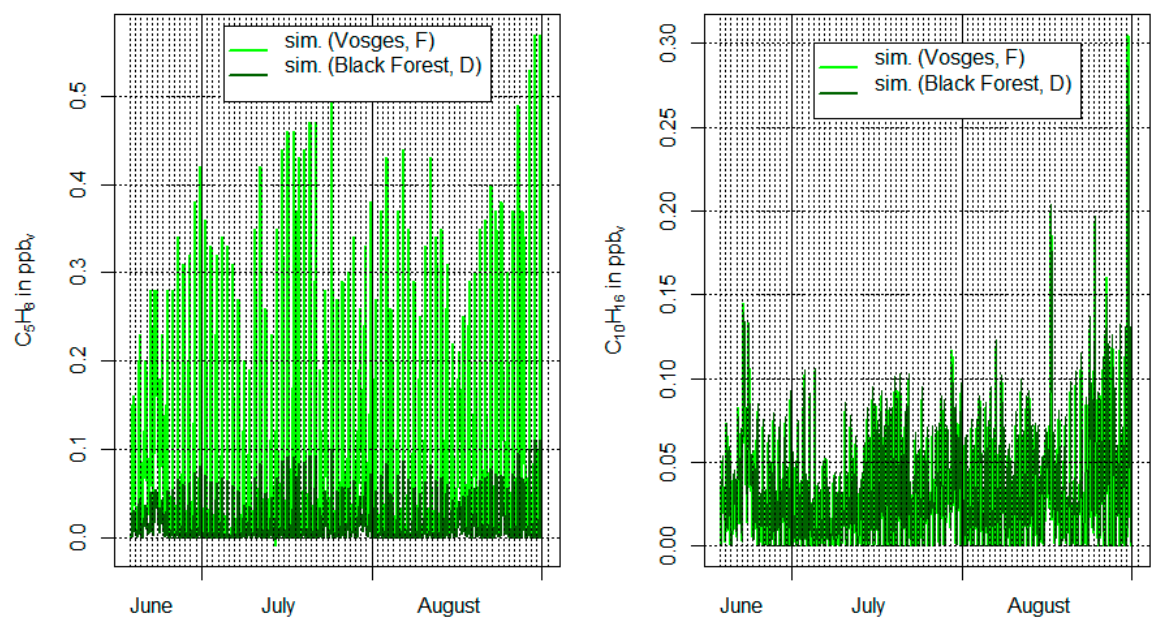

Figure 3. Estimated average summertime isoprene (left) and monoterpene (right) mixing ratios above the Vosges forest type and Black Forest type forest. Light green represents Vosges forest type conditions and dark green Black Forest type ones.

\subsubsection{Effect of Isoprene and Monoterpenes}

The different BVOC emission strengths and corresponding ambient mixing ratios result in ground level ozone pollution changes between -3 and $+35 \%$ above the forests of elevated isoprene emissions (Alsatian Vosges mixture forest) or several $\mathrm{ppb}_{\mathrm{v}}$ (Figure 4). The larger the isoprene emission increase, the higher the ozone increase. On the contrary, monoterpenes have two opposite effects: (i) the increase of non-methane hydrocarbons (NMHC) yielding elevated ozone production; and (ii) the formation of SOA-i.e., reduction of gaseous VOCs by absorption to the particulate phase. Especially lhe latter onecan display notable strength: -19 to $+2 \%$ for Vosges mixture type and -9 to $+9 \%$ for Black Forest type forests. The mean effect is negative for both types of forest and non-negligible. 

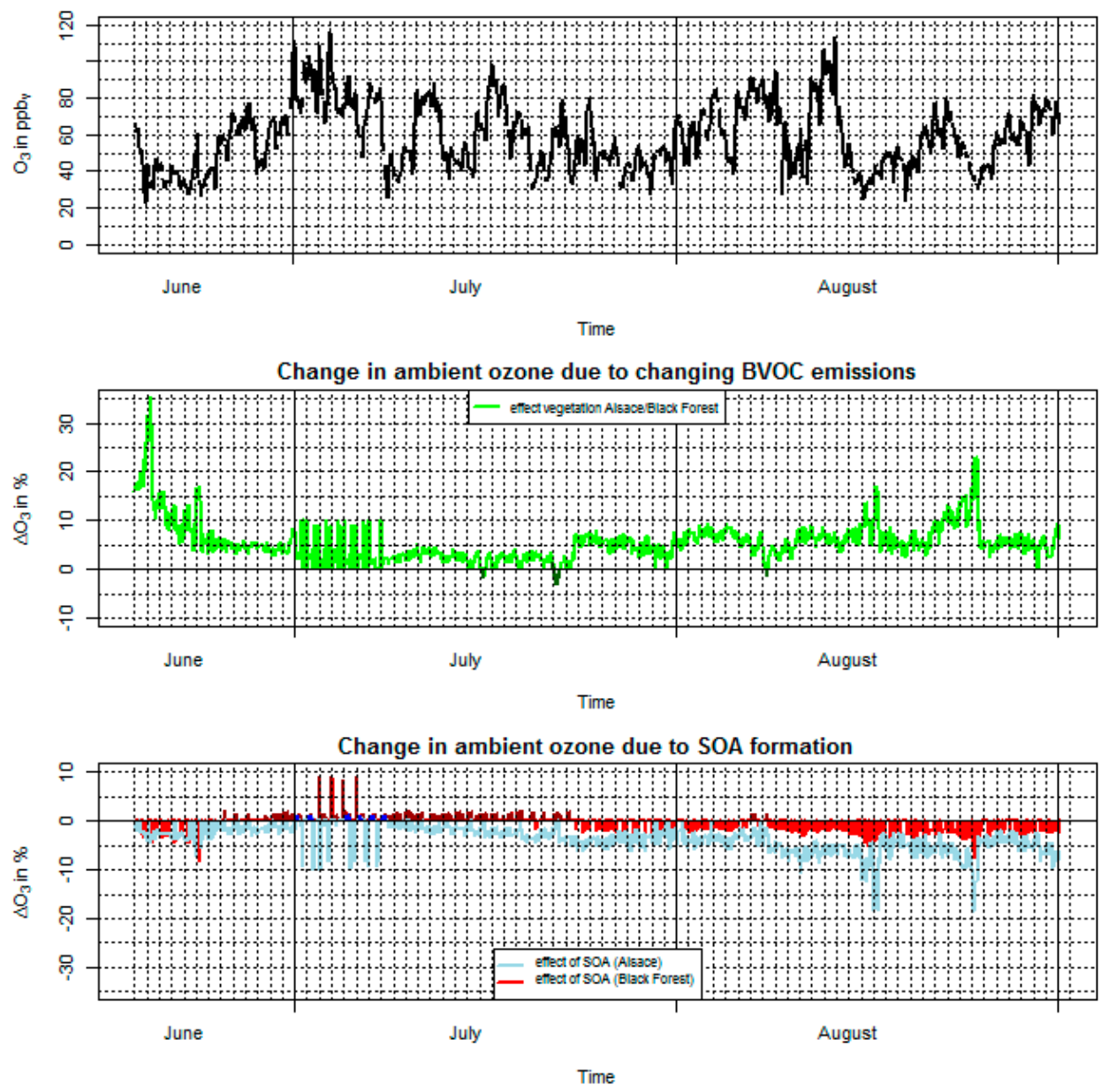

Figure 4. Summertime tropospheric (ground level) ozone mixing ratio: Observations in the Black Forest (top), effect of changing tree species contributions (middle) and of secondary organic aerosol (bottom).

\subsubsection{Implications for Organic Aerosol Particles}

The total implications for ambient particulate matter concentrations tends to be minor and can change direction. If external SOA masses are advected and repartitioned to the gas-phase to a certain extent, they will intensify ozone production, while BVOCs emitted at the site of interest will either contribute to ozone formation or partition to the particle phase and will be therefore unable to join ozone production. The first effect is positive-e.g., for the Black Forest, a median of $+31 \%$ is derived - and for the second effect a negative impact was calculated (e.g., the Black Forest median August 2015: $-14 \%$ ) with different intensities throughout the day. Therefore, although the total SOA effect tends to be minor (Figure 5), opposing effects may be major and show up if the local situation is disturbed by local wind. With respect to the estimated total SOA mass concentration changes due to different emissions and oxidation between both forest types are about $0.5 \mu \mathrm{g} / \mathrm{m}^{3}$, which is less than $3 \%$ (Figure 5, on the left). The magnitude of the effect is related to different temperatures and the competition between higher emissions and organic aerosol mass precursor formation and the increased volatility of semi-volatile aerosol species.

The effect of different forest types becomes more evident for the estimated biogenic new particle formation rates [53] (Figure 6), which are relevant for total particle number concentration and indirect climate feedback processes such as cloud properties $[14,15]$. Despite a notable daily scattering in the ratio of the formation rate at $D_{p}=3 \mathrm{~nm}$ of the Black Forest type to Alsatian Vosges type conditions, the change of different weather systems and temperature is clearly visible. A daily mean enhancement of formation rates under the Black Forest conditions of between $109 \% \pm 25 \%$ compared to the Alsatian 
Vosges conditions can be seen. This can be explained by different emission characteristics that are influenced by daily mean temperature ( $84.4 \%$, Pearson's correlation coefficient). In this context, a major aspect of uncertainty is the emission of individual sesquiterpenes and thus mean reactivity, which are affected by different tree species, tree injuries, sesquiterpene specification and the local variation of needle/leaf temperatures [44]. In our case, the mean reactivity of sesquiterpenes with ozone was assumed to be $\mathrm{k}\left(\mathrm{sqt}, \mathrm{O}_{3}\right)=4 \times 10^{-16} \mathrm{~cm}^{3} \mathrm{molec}^{-1} \mathrm{~s}^{-1}$ based on individual sesquiterpene emission contributions for different species [54-56] and the corresponding reaction rate coefficients [33]. Please note that our calculations provide an average response for a mean forest tree type mixture. Heterogeneity of vegetation and variability of atmospheric trace gases will cause a remarkable scattering, even in suburban areas not directly affected by traffic emissions of particles, as seen in Berlin [57].
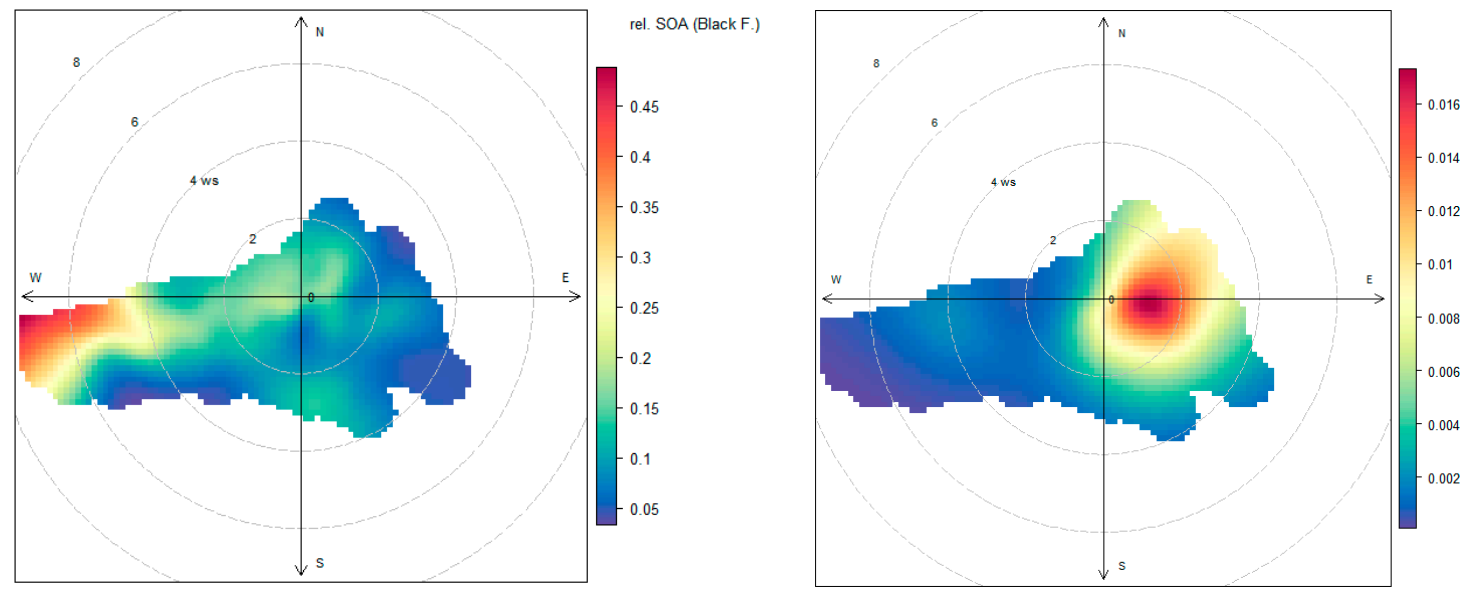

Figure 5. Changing forest ecosystem composition (Alsatian Vosges forest to Black Forest) and its consequences for ambient SOA mass concentrations. Left: intensities of calculated SOA as a function of wind speed and direction at Muenstertal; Right: absolute calculated SOA difference in $\mu \mathrm{g} / \mathrm{m}^{3}$ as a function of wind speed and direction at Muenstertal.

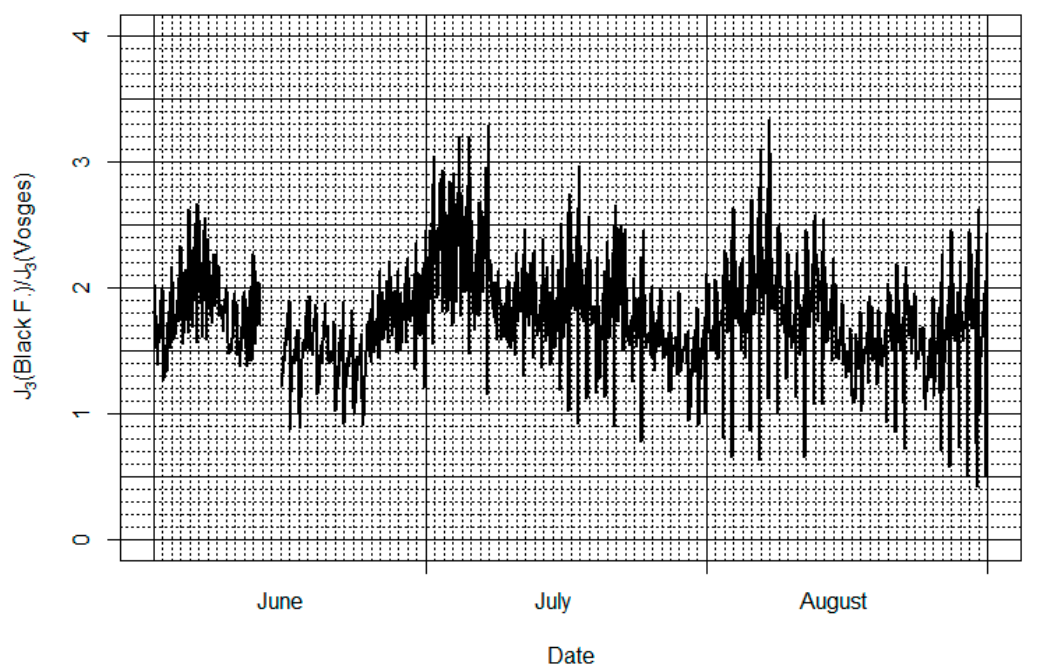

Figure 6. Forest effect on newly formed aerosol particles from natural sources [40] during the summer. Ratio of particle formation rates in Black Forest and the Vosges area. 


\subsubsection{Implications for $\mathrm{OH}, \mathrm{HO}_{2}$ and Nitrogen Species}

The changing emissions of BVOCs influences the cleansing capacity of the atmosphere and the $\mathrm{NO}$ lifetime. In the Black Forest, $\mathrm{OH}$ concentration was calculated to be approximately $5 \%$ (25th percentile: $10 \%$, 75th percentile: $2 \%$ ) smaller than in the Alsatian Vosges type forest. An even stronger effect was found for $\mathrm{HO}_{2}:-17$ (25th perc.: $-25 \%$, 75th perc.: $-12 \%$ ). While isoprene intensifies the tropospheric ozone production cycle [58], monoterpenes tend to bind the hydroperoxy radical as organic hydroperoxide and to slow down the reformation of $\mathrm{OH}$. Therefore, the lifetime of nitrogen monoxide is increased by exactly $5 \%$ and moderately increases its reaction rate with ozone yielding $\mathrm{NO}_{2}$. In the presence of sunlight, ozone is formed back (null cycle). In the presence of organic peroxy radicals, organic nitrates are formed to a higher extent, which have longer residence times either in the gas- or particle-phases [59] and reduce the cycling intensity between $\mathrm{NO}$ and $\mathrm{NO}_{2}$ with respect to ozone production.

\subsection{Effects of Temperature}

Several important aspects require further investigation: (i) temperature; (ii) soil water content; and (iii) ecosystem interactions, of which only the first one is accessible for the box model approach used here based on publications. While a general parameterization for soil water content (SWC) that is impact independent of tree species is available [45]—i.e., including reduction of emissions down to $40 \%$ SWC at the wilting point, this point is expected to be species-specific and would influence the results depending on SWC significantly. Consideration of these feedback processes within ecosystems requires a more detailed knowledge of drought tolerance and interactions of the individual species significantly contributing to the forest. This is currently lacking and was therefore not included in this study.

In changing climate conditions, PAR will not change as GR will stay put. But infrared radiation will enhance and will be trapped within the Earth's climate system [60]. The mean temperature will increase and so will enzyme activity, until its upper limits has been reached and until the storage pools of terpenes, such as resin ducts, have been emptied. Because of that, we kept all conditions-i.e., $\mathrm{NO}_{\mathrm{x}}$, anthropogenic VOCs, global and photosynthetical radiation-fixed, and varied temperature in the range of +0 up to $+8 \mathrm{~K}$ compared to the present conditions as described by the IPCC report [60]. Therefore, the speed of the chemical reaction will be enhanced because of enhanced collision rates, biogenic emissions will increase as they are linked to increased temperatures, and SOA will evaporate or form to a smaller extent according to changing saturation vapour pressures and partitioning coefficients.

Figures 7 and 8 present the simulation results for August 2015. As temperature and biogenic emissions increase, ozone is formed more rapidly and intensely, which is dampened by BVOC reactions with ozone and by formation of larger organic hydroperoxides and nitrates, gently reducing $\mathrm{NO}_{\mathrm{x}}$ availability and tropospheric ozone production. This is reflected in the development of daily ground level ozone maxima (Figure 8), which increase continuously as temperatures increase.

Similar observations can be made for SOA production differences between both forest types. Although being insignificant at temperatures smaller than $30^{\circ} \mathrm{C}$, the situation changes above this temperature. At $30.1 \pm 1.1{ }^{\circ} \mathrm{C}$ the SOA effect becomes more intense for Black Forest type forests compared to both Alsatian-i.e., Alsace in general and Alsatian Vosges-type forests and intensifies at higher temperatures. This originates from the higher contribution $\mathrm{f}$ of stored monoterpenes at Black Forest type compared to Vosges mixture type forests for standard conditions at $\mathrm{T}=30^{\circ} \mathrm{C}\left(\mathrm{f}\left(\mathrm{E}_{\mathrm{MT}}\right.\right.$, stored, Black Forest $)=0.44, \mathrm{f}\left(\mathrm{E}_{\mathrm{MT}}\right.$, stored, Alsatian Vosges forest $\left.)=0.38\right)$. As temperature increases the mean stored monoterpene emission increases by $0.139 / \mathrm{K}$ for both forest types, while the de novo monoterpene emission (PAR and T dependent) only increases by about $0.04 / \mathrm{K}$. Thus, the relative importance of the stored monoterpene resources grows with ascending temperatures. 

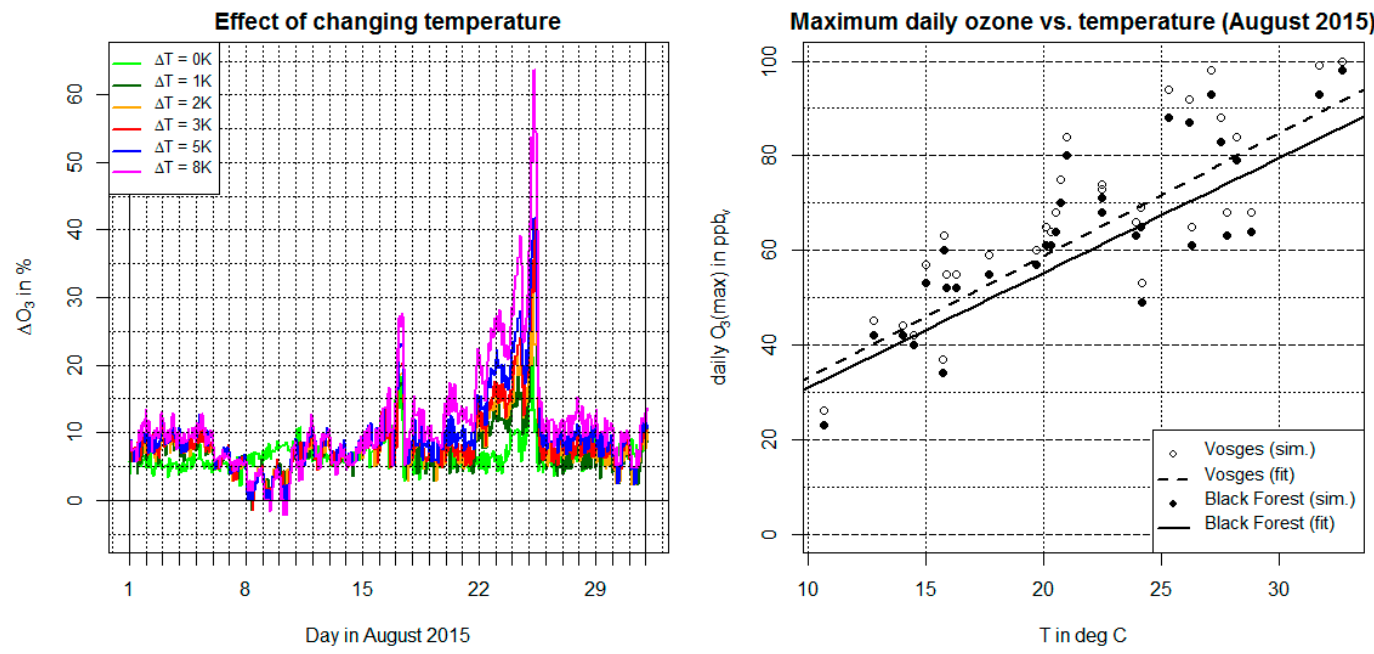

Figure 7. Change in boundary layer ozone mixing ratio because of changing air temperature for August 2015 as timeline (left) and as daily max vs. temperature (right).

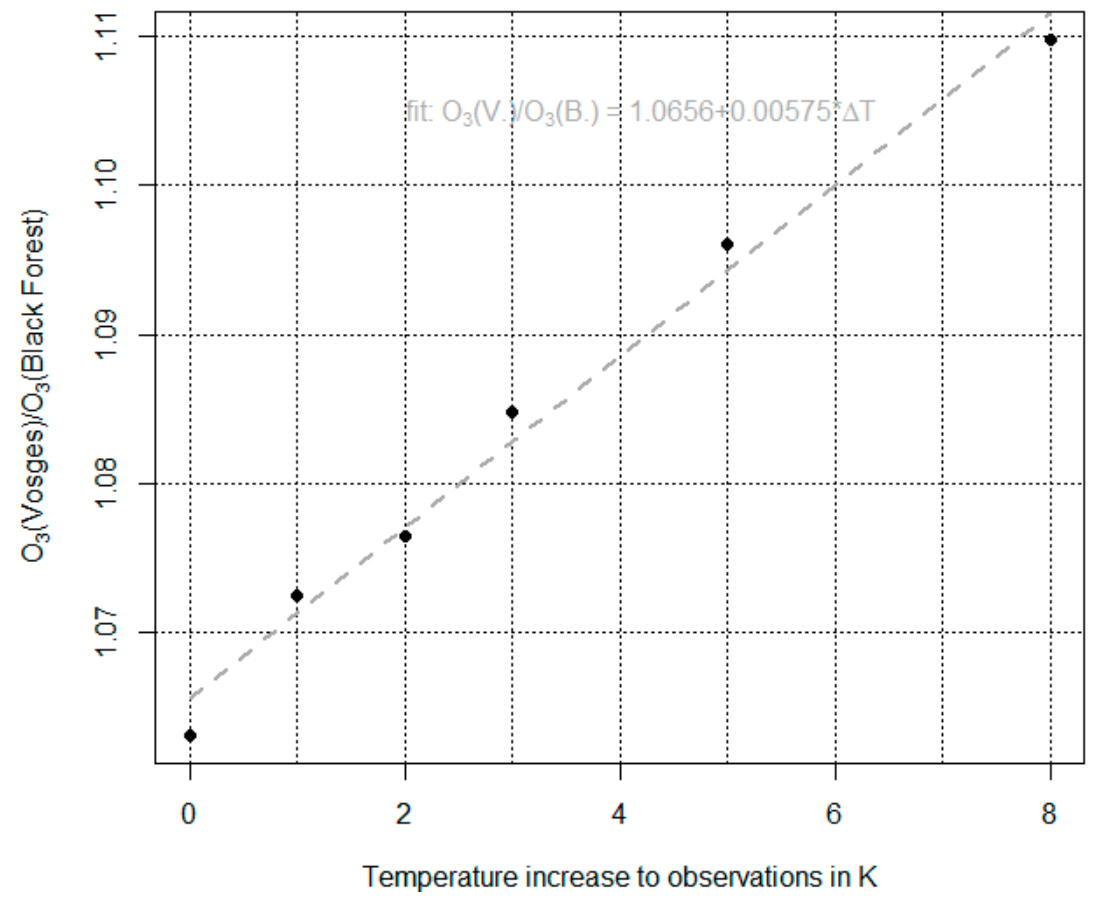

Figure 8. Effect of temperature on calculated ozone differences for different forest compositions.

This becomes more evident when checking the wind direction and speed. Apparently, the maximum intensity of calculated SOA is linked to westerly wind directions (max. temperatures) and the highest wind speeds (precursors from regional emissions and beyond; Figure 4, bottom left). However, the largest differences display with local very moderate winds from the East (Figure 4, bottom right), i.e., the forested areas with a dominance of biogenic VOCs and longest local residence time.

\subsection{Effect of Reducing Input Information}

So far, we have considered the influence of different parameters such as different BVOC groups, nitrogen oxides, deposition velocities and temperature on the simulation results and reproduction of observations. Finally, we check the effects of information reduction-i.e., reduction of complexity in simulation-as most models tend to be simple or belong to a larger set of processes to be 
calculated-competing for computational speed and space. Therefore, we omit stepwise biogenic VOC details and related processes described within the detailed box. We start by reducing two considered monoterpenes to a single one (test A), then cut down the monoterpene emission calculation from the sum of de novo and storage pool emissions to storage pool emissions according to Guenther et al. $[45,46]$ only (test B). In the following steps, we omit the consideration of SOA (step C) and skip including monoterpenes at all (step D). Finally, all biogenic VOCs-i.e., isoprene too-are neglected (step E).

The resulting features are diverse: There is no significant change in correlation coefficients of observed and simulated ground level ozone at one hour time resolution (daily pattern), while shorter periods do vary gently and the simulated absolute amount of ozone changes notably (Table 5). At warm summer maximum temperatures of $35^{\circ} \mathrm{C}$ two groups can be identified, one representing ground level ozone reducing effects such as monoterpenes (the more the less) and one referring to tropospheric ozone enhancement like SOA and isoprene (the more the more). It is quite interesting that more details on monoterpene emissions and structure do not influence ozone calculations to a significant extent (Table 5). If we assume all monoterpenes to be represented by $\alpha$-pinene, there is no remarkable modification of a monoterpene mixture or $\beta$-pinene only. Furthermore, emission from storage pools or via de novo synthesis does not change the calculations with respect to ozone. But effects show up for SOA and the related feedback, which is strongest. The strength of individual effects is linked to the tree species and the dominant emission types. For an isoprene emission dominated forest type, for example in the Alsatian Vosges the isoprene related ground level ozone effect would be much more pronounced.

Table 5. Relative ozone increases at $\mathrm{T}=35^{\circ} \mathrm{C}$ compared to reference simulation.

\begin{tabular}{cc}
\hline Parametre & $\Delta \mathbf{O}_{3} / \mathbf{O}_{3}$ (Black Forest, ref.) \\
\hline MTs $=\alpha$-pinene & $+0.55 \pm 0.10$ \\
MTs $=\beta$-pinene & $+0.55 \pm 0.10$ \\
MT emission from storage pools only & $+0.55 \pm 0.10$ \\
no SOA & $-1.89 \pm 0.33$ \\
no MTs & $+0.56 \pm 0.10$ \\
no isoprene & $-0.03 \pm 0.01$ \\
no BVOCs & $+0.55 \pm 0.09$ \\
\hline
\end{tabular}

If we investigate the behaviour at different ambient temperatures, some aspects display a rather constant contribution such as monoterpenes, which represent the major BVOC released by Black Forest trees. Other aspects, like SOA, provide a significantly changing effect with changing temperatures. At cooler temperatures of 20 to $25^{\circ} \mathrm{C}$, neglecting ozone results in overstimulation of ground level ozone because of a missing sink for gaseous VOCs, while at higher temperatures beyond $25{ }^{\circ} \mathrm{C}$ ignoring SOA leads to an underestimation, due to the missing source of VOCs re-evaporating for the particle phase (Figure 9), which is important for typical summertime conditions of $35^{\circ} \mathrm{C}$ and above. At these conditions, typical for high ozone mixing ratios, several of the named tests (A)-(E) cause notable changes. As a summary, we can conclude: In the case of Black Forest species and conditions, considering no isoprene does not have significant effects on ozone because of its minor total emission rate. Neglecting monoterpenes causes approximately $70 \%$ higher ozone values at a temperature of $35{ }^{\circ} \mathrm{C}$. It is worth mentioning that several of these effects may counteract and finally only a small to medium change (test E, "no BVOCs", Table 5) is detectable. However, this mean result is not necessarily correct for extremes such as ozone maxima and night time episodes. 

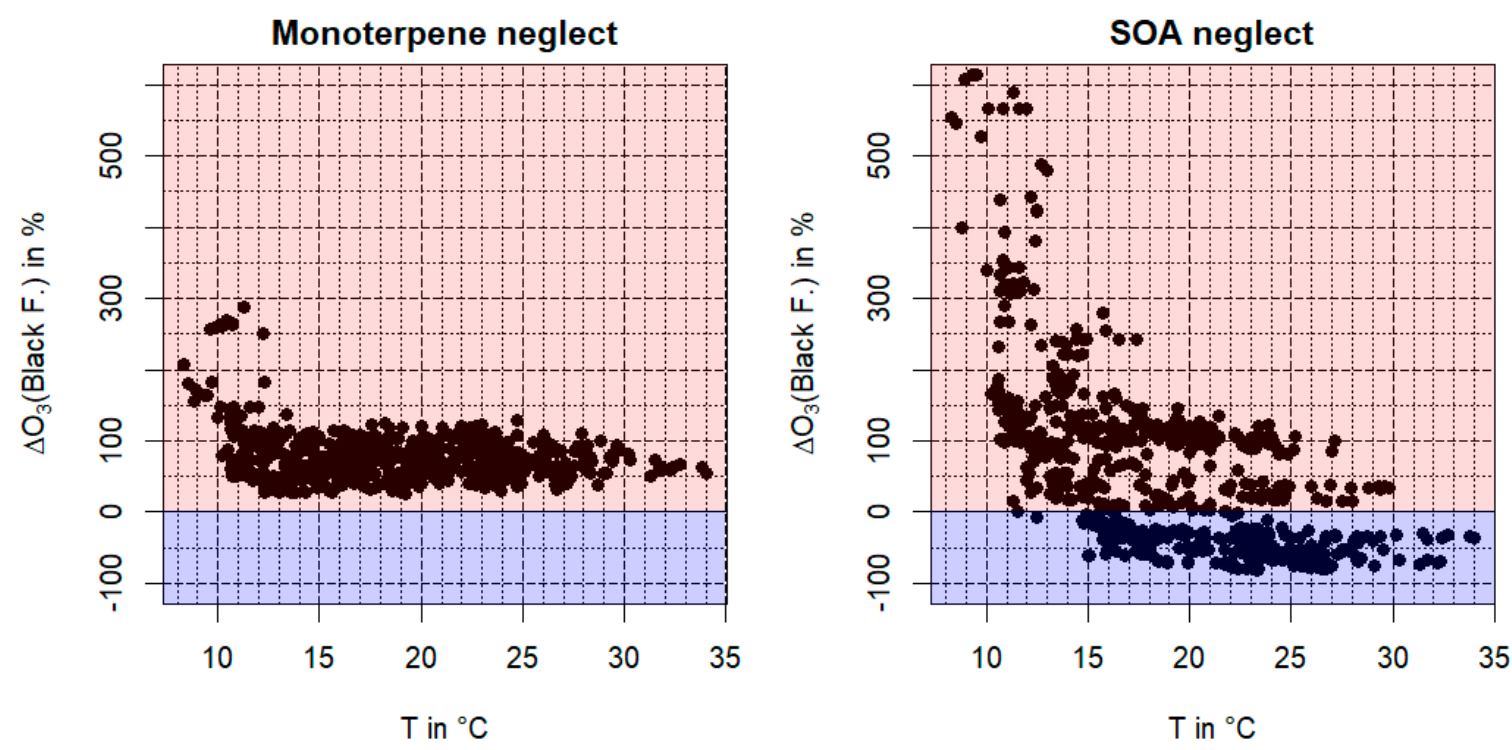

Figure 9. Effect of neglect on ozone calculated, left: monoterpenes; right: secondary organic aerosol.

\section{Discussion}

In this study, we have demonstrated that:

- Isoprene emission controlled forests like those in Alsace (especially the Vosges) leads to more intense tropospheric ozone formation during summer, than forests with both, i.e., monoterpene and isoprene emissions such as those in the Black Forest, if identical environmental conditions are assumed. This is caused by different oxidation product characteristics and SOA formation and is especially true for the transition from higher to lower $\mathrm{NO}_{\mathrm{x}}$ concentrations, limiting the ozone production at the background site observation.

- The difference in formation intensifies with increasing temperatures and was found for other areas too. Churkina et al. [61] and Curci et al. [62] found a significant link between biogenic emission, summer temperatures and ground level ozone concentrations at urban [61] and remote areas [62]. Depending on the species mixture and resulting emission strengths tropospheric-i.e., ground level-ozone was found to increase notably.

- The particle formation rates from biogenic sources will remarkably intensify in cases where additional pollution does not reduce the lifetime of novel particles to a substantial extent. Additionally, a substantial local variability is to be expected, depending on tree species distribution and corresponding BVOC (mono- and sesquiterpene) emissions and varying environmental conditions [58].

- The production of SOA mass and volume differs depending on the BVOC emissions. High isoprene emissions will have different effects than high monoterpene emission rates as the oxidation degree is expected to be reduced ( $\mathrm{OH}$ reduction) and the volatility of the products and potential SOA precursors will rise.

- Among the environmental factors influencing plant BVOC emission, water availability in the soil might be particularly important, especially when considering climate predictions [63]. The expected reduced summer precipitation, for example, in Southern and Central Europe, might considerably lower soil water availability in the future. The forecasted higher air temperatures will enhance this trend because of stimulated soil water evaporation. In a very first reaction towards drought, plants close their stomata to avoid loss of water by transpiration. Consequently, the cooling effect of transpiration is reduced leading to increased leaf temperatures, which might enhance leaf-internal VOC production [64]. Since $\mathrm{CO}_{2}$ enters the leaves via the stomata, drought affects photosynthesis, causing lowered rates of $\mathrm{C}$ fixation. The effects of drought stress on 
tree BVOC emissions are complex and are still not fully understood, since many factors-such as plant species and provenance, duration and severity of the stress, and also the nature and biosynthetic pathway of the volatile compound-seem to play an important role. Because drought stress often co-occurs with elevated air temperatures, the combined effect of both factors also has to be taken into account. Several studies have indicated that moderately reduced soil water availability does not affect or rather slightly stimulates isoprenoid emissions [65-67]. In contrast, strongly reduced water availability affects the biosynthesis of isoprenoids, thereby decreasing their emissions [66-73]. This effect is most likely due to the reduced availability of the substrate of the relevant biosynthetic pathways due to strongly impaired photosynthesis. In contrast, emission of stress-induced compounds, such as sesquiterpenes or green leaf volatiles (products of the lipoxygenase reaction) can increase in response to drought stress [65,72]. The results of our simulations could be affected by better considering the influence of drought and heat on BVOC emission, which most likely strongly depends on individual tree species' drought sensitivity. There is certainly a lack of knowledge on the impacts of abiotic and biotic stressors, which should be resolved in order to realistically explain the capacity of ecosystems to cope with climate changes and to understand individual climate feedback process strengths.

- This box model study had the advantage of investigating processes more deeply and with a higher time resolution than regional models. However, the attribution of future changes and the feedback's most accurate 3D-regional model simulations would be favourable, although they could cause some other notable shortcomings such as reduced chemistry schemes, input information and averages for a mixed type forest! Benefits may arise for not-very-short-lived chemical species (>30 min). But challenges may arise for highly variable processes such as $\mathrm{OH}$ and particle formation.

\section{Conclusions}

To conclude, the type of forest and the contribution of individual tree species are important factors that influence the forests' survival in future climate conditions and the corresponding feedback processes that affect not only vegetation but also human health via e.g., ozone and ultrafine particulates $[60,73]$. So far, the Alsace and thus the corresponding Vosges forests benefit from the missing substantial traffic $\mathrm{NO}_{x}$ resources, which are elevated in the Upper Rhine valley at the Eastern part. But Black Forest areas would experience notably higher pollution levels if higher isoprene emitter species would join or replace the current species emitting a BVOCs mix.

In order to accurately simulate these feedback processes several important features are needed:

i a chemical scheme with sufficient details, i.e., with respect to isoprene and monoterpenes: peroxy radical and major products chemistry;

ii an incorporation of SOA formation and evaporation allowing a continuous equilibration between gas- and particle-phases and not a one directional description;

iii Inclusion of more detailed individual forest species characteristics, i.e., emissions and stress tolerance such as temperature coefficient and drought tolerance. Calculation of organic particle formations in number and mass clearly benefits from consideration of a detailed description of de novo production and emission from storage pools.

The latter would provide much more detailed information and feedback on the stress tolerance of the investigated forests or ecosystems. While reduced chemical schemes are essential for atmospheric chemistry effects to be calculated for approaches that are larger either spatially or in complexity, there will be shortcomings, especially with regard to the effects of monoterpene on $\mathrm{HO}_{2}$ and $\mathrm{SOA}$. A decision about complexity of these schemes should always be made within the context of the question to be answered.

Supplementary Materials: The following are available online at www.mdpi.com/2225-1154/5/4/78/s1, Table S1: Basal sesquiterpene emission factors $\mathrm{E}_{0}$ and temperature coefficients for of the individual tree species considered. 
Acknowledgments: The calculations are made possible by substantial data supplied by the Landesamt für Umwelt Baden-Württemberg in Stuttgart, Germany, by Pierre Robellet from ATMO Grand Est in Schiltigheim, France (ASPA) and by the Karlsruhe Institute of Technology (KIT) for server access and space for running the box model. Thanks to the FVA in Baden-Wuerttemberg, which provided the datasets of the inventory 2012 for calculating the dry weight biomass and for expert support. All the work was made possible by the Waldklimafond project "BuTaKli" (Buchen-Tannen-Mischwälder zur Anpassung von Wirtschaftswäldern an Extremereignisse des Klimawandels) (project number $28 \mathrm{~W}-\mathrm{C}-1-069-01)$, which is highly acknowledged.

Author Contributions: B.B. designed and ran the experiments; F.S., T.B. and O.A. investigated and extracted the different forest compositions and parameters. J.K. supplied missing species emission rates, checked the formulation of BVOC emissions in detail and discussed water effects; R.Y. contributed and discussed the growth effects of tropospheric ozone on forests.

Conflicts of Interest: There are no conflicts of interest.

\section{References}

1. Lelieveld, J.; Evans, J.S.; Fnais, M.; Giannadaki, D.; Pozzer, A. The contribution of outdoor air pollution sources to premature mortality on a global scale. Nature 2015, 525, 367-371. [CrossRef] [PubMed]

2. Matyssek, R.; Innes, J.L. Ozone-A risk factor for trees and forests in Europe? Water Air Soil Pollut. 1999, 116, 199-226. [CrossRef]

3. Pretzsch, H.; Dieler, J.; Matyssek, R.; Wipfler, P. Tree and stand growth of mature Norway spruce and European beech under longterm ozone fumigation. Environ. Pollut. 2010, 158, 1061-1070. [CrossRef] [PubMed]

4. Augustaitis, A.; Kliučius, A.; Marozas, V.; Pilkauskas, M.; Augustaitiene, I.; Vitas, A.; Staszewski, T.; Jansons, A.; Dreimanis, A. Sensitivity of European beech trees to unfavorable environmental factors on the edge and outside of their distribution range in northeastern Europe. iForest 2014, 9, 259-269. [CrossRef]

5. Novak, K.; Schaub, M.; Fuhrer, J.; Skelly, J.M.; Frey, B.; Kräuchi, N. Ozone effects on visible foliar injury and growth of Fagus sylvatica and Viburnum lantana seedlings grown in monoculture origin mixture. Environ. Exp. Bot. 2008, 62, 212-220. [CrossRef]

6. De Vries, W.; Dobbertin, M.H.; Solberg, S.; van Dobben, H.F.; Schaub, M. Impacts of acid deposition, ozone exposure and weather conditions on forest ecosystems in Europe: An overview. Plant Soil 2014, 380, 1-45. [CrossRef]

7. Loreto, F.; Velikova, V. Isoprene produced by leaves protects the photosynthetic apparatus against ozone damage, quenches ozone products, and reduces lipid peroxidation of cellular membranes. Plant Physiol. 2001, 127, 1781-1787. [CrossRef] [PubMed]

8. Bergmann, E.; Bender, J.; Weigel, H.J. Impact of tropospheric ozone on terrestrial biodiversity: A literature analysis to identify ozone sensitive taxa. J. Appl. Bot. Food Qual. 2017, 90, 83-105. [CrossRef]

9. Jud, W.; Fischer, L.; Canaval, E.; Wohlfahrt, G.; Tissier, A.; Hansel, A. Plant surface reactions: An opportunistic ozone defence mechanism impacting atmospheric chemistry. Atmos. Chem. Phys. 2016, 16, 277-292. [CrossRef]

10. Bourtsoukidis, E.; Bonn, B.; Dittmann, A.; Hakola, H.; Hellen, H. Ozone stress as a driving force of sesquiterpene emissions: A suggested parameterization. Biogeosciences 2012, 9, 4337-4352. [CrossRef]

11. Giron-Calva, P.S.; Li, T.; Blande, J.D. Volatile-Mediated Interactions between Cabbage Plants in the Field and the Impact of Ozone Pollution. J. Chem. Ecol. 2017, 43, 339-350. [CrossRef] [PubMed]

12. Jenkin, M.E.; Young, J.C.; Rickard, A.R. The MCM v3.3.1 degradation scheme for isoprene. Atmos. Chem. Phys. 2015, 15, 11433-11459. [CrossRef]

13. Jenkin, M.E. Modelling the formation and composition of secondary organic aerosol from $\alpha$ - and $\beta$-pinene ozonolysis using MCM v3. Atmos. Chem. Phys. 2004, 4, 1741-1757. [CrossRef]

14. Jacobson, M.Z. Fundamentals of Atmospheric Modeling, 2nd ed.; Cambridge University Press: Cambridge, UK, 2005; p. 828. ISBN 978-0521548656.

15. Seinfeld, J.H.; Pandis, S.N. Atmospheric Chemistry and Physics: From Air Pollution to Climate Change, 2nd ed.; J. Wiley \& Sons: Hoboken, NJ, USA, 2006; p. 1232. ISBN 978-0471720188.

16. Calfapietra, C.; Fares, S.; Loreto, F. Volatile organic compounds from Italian vegetation and their interaction with ozone. Environ. Pollut. 2009, 157, 1478-1486. [CrossRef] [PubMed] 
17. Fiore, A.M.; Levy, H., II; Jaffe, D.A. North American isoprene influence on intercontinental ozone pollution. Atmos. Chem. Phys. 2011, 11, 1697-1710. [CrossRef]

18. Paoletti, E.; De Marco, A.; Beddows, D.C.S.; Harrison, R.M.; Manning, W.J. Ozone levels in European and USA cities are increasing more than at rural sites, while peak values are decreasing. Environ. Pollut. 2014, 192, 295-299. [CrossRef] [PubMed]

19. Sicard, P.; Serra, R.; Rossello, P. Spatiotemporal trends in ground-level ozone concentrations and metrics in France over the time period 1999-2012. Environ. Res. 2015, 149, 122-144. [CrossRef] [PubMed]

20. Sicard, P.; Augustaitis, A.; Belyazid, S.; Calfapietra, C.; de Marco, A.; Fenn, M.; Bytnerowicz, A.; Grulke, N.; He, S.; Matyssek, R.; et al. Global topics and novel approaches in the study of air pollution, climate change and forest ecosystems. Environ. Pollut. 2016, 213, 977-987. [CrossRef] [PubMed]

21. Goldstein, A.H.; Galbally, I.E. Known and Unexplored Organic Constituents in the Earth's Atmosphere. Environ. Sci. Technol. 2007, 41, 1514-1521. [CrossRef] [PubMed]

22. Jenkin, M.E.; Saunders, S.M.; Pilling, M.J. The tropospheric degradation of volatile organic compounds: A protocol for mechanism development. Atmos. Environ. 1997, 31, 81-104. [CrossRef]

23. Bloss, C.; Wagner, V.; Jenkin, M.E.; Volkamer, R.; Bloss, W.J.; Lee, J.D.; Heard, D.E.; Wirtz, K.; Martin-Reviejo, M.; Rea, G.; et al. Development of a detailed chemical mechanism (MCMv3.1) for the atmospheric oxidation of aromatic hydrocarbons. Atmos. Chem. Phys. 2005, 5, 641-664. [CrossRef]

24. Saunders, S.M.; Jenkin, M.E.; Derwent, R.G.; Pilling, M.J. Protocol for the development of the Master Chemical Mechanism, MCM v3 (Part A): Tropospheric degradation of nonaromatic volatile organic compounds. Atmos. Chem. Phys. 2003, 3, 161-180. [CrossRef]

25. Jenkin, M.E.; Wyche, K.P.; Evans, C.J.; Carr, T.; Monks, P.S.; Alfarra, M.R.; Barley, M.H.; McFiggans, G.B.; Young, J.C.; Rickard, A.R. Development and chamber evaluation of the MCM v3.2 degradation scheme for $\beta$-caryophyllene. Atmos. Chem. Phys. 2012, 12, 5275-5308. [CrossRef]

26. Stockwell, W.R.; Middleton, P.; Chang, J.S.; Tang, X. The second generation regional Acid Deposition Model chemical mechanism for regional air quality modeling. J. Geophys. Res. 1990, 95, 16343-16367. [CrossRef]

27. Stockwell, W.R.; Kirchner, F.; Kuhn, M.; Seefeld, S. A new mechanism for regional atmospheric chemistry modeling. J. Geophys. Res. 1997, 102, 25847-25879. [CrossRef]

28. Knote, C.; Tuccella, P.; Curci, G.; Emmons, L.; Orlando, J.J.; Madronich, S.; Baró, R.; Jimenez-Guerrero, P.; Luecken, D.; Hogrefe, C.; et al. Influence of the choice of gas-phase mechanism on predictions of key gaseous pollutants during the AQMEII phase-2 intercomparison. Atmos. Environ. 2015, 115, 553-568. [CrossRef]

29. Mazzuca, G.M.; Ren, X.; Loughner, C.P.; Estes, M.; Crawford, J.H.; Pickering, K.E.; Weinheimer, A.J.; Dickerson, R.R. Ozone production and its sensitivity to NOx and VOCs: Results from the DISCOVER-AQ field experiment, Houston 2013. Atmos. Chem. Phys. 2016, 16, 14463-14474. [CrossRef]

30. Kuik, F.; Lauer, A.; Churkina, G.; Denier van der Gon, H.A.C.; Fenner, D.; Mar, K.A.; Butler, T.M. Air quality modelling in the Berlin-Brandenburg region using WRF-Chem v3.7.1: Sensitivity to resolution of model grid and input data. Geosci. Model Dev. 2016, 9, 4339-4363. [CrossRef]

31. Butler, T.; Lawrence, M.; Taraborrelli, D.; Lelieveld, J. Multi-day ozone production potential of volatile organic compounds calculated with a tagging approach. Atmos. Environ. 2011, 45, 4082-4090. [CrossRef]

32. Bonn, B.; von Schneidemesser, E.; Butler, T.; Churkina, G.; Ehlers, C.; Grote, R.; Klemp, D.; Nothard, R.; Schäfer, K.; von Stülpnagel, A.; et al. Impact of vegetative emissions on urban ozone and biogenic secondary organic aerosol: Box model study for Berlin, Germany. J. Clean. Prod. 2017. submitted.

33. Atkinson, R.; Baulch, D.L.; Cox, R.A.; Crowley, J.N.; Hampson, R.F.; Hynes, R.G.; Jenkin, M.E.; Rossi, M.J.; Troe, J. IUPAC Subcommittee Evaluated kinetic and photochemical data for atmospheric chemistry: Volume II-Gas phase reactions of organic species. Atmos. Chem. Phys. 2006, 6, 3625-4055. [CrossRef]

34. Pankow, J.F. An absorption-model of the gas aerosol partitioning involved in the formation of secondary organic aerosol. Atmos. Environ. 1994, 28, 189-193. [CrossRef]

35. Birmili, W.; Weinhold, K.; Rasch, F.; Sonntag, A.; Sun, J.; Merkel, M.; Wiedensohler, A.; Bastian, S.; Schladitz, A.M.; Löschau, G.; et al. Long-term observations of tropospheric particle number size distributions and equivalent black carbon mass concentrations in the German Ultrafine Aerosol Network (GUAN). Earth Syst. Sci. Data 2016, 8, 355-382. [CrossRef]

36. Prank, M.; Sofiev, M.; Tsyro, S.; Hendriks, C.; Semeena, V.; Francis, X.V.; Butler, T.; Denier van der Gon, H.; Friedrich, R.; Hendricks, J.; et al. Evaluation of the performance of four chemical transport models in predicting the aerosol chemical composition in Europe in 2005. Atmos. Chem. Phys. 2016, 16, 6041-6070. [CrossRef] 
37. Inventaire Forestier. 2016. Available online: http://inventaire-forestier.ign.fr/spip/ (accessed on 20 November 2016).

38. Kändler, G.; Cullmann, D. (Eds.) Report: Regionale Auswertung der Bundeswaldinventur 3 Wuchsgebiet Schwarzwald; FVA: Baden-Württemberg, Germany, 2016.

39. Nabuurs, G.J.; Ravindranath, N.H.; Paustian, K.; Freibauer, A.; Hohenstein, W.; Makundi, W. LUCF sector good practice guidance. In IPCC: Good Practice Guidance for Land Use, Land Use Change and Forestry; Penman, J., Gytarsky, M., Hiraishi, T., Krug, T., Kruger, D., Pipatti, R., Buendia, L., Miwa, K., Ngara, T., Tanabe, K., Wagner, F., Eds.; Institute for Global Environmental Strategies: Kanagawa, Japan, 2003; ISBN 4-88788-003-0.

40. CITEPA. 2011. Available online: http://www.citepa.org/emissions (accessed on 20 November 2016).

41. Szinyei, D. Modelling and Evaluation of Ozone Dry Deposition. PhD thesis, Free University, Berlin, Germany, 2014.

42. Tiwari, S.; Grote, R.; Churkina, G.; Butler, T. Ozone damage, detoxification and the role of isoprenoids-New impetus for integrated models. Funct. Plant Biol. 2016, 43, 324-336. [CrossRef]

43. Dumont, J.; Keski-Saari, S.; Keinänen, M.; Cohen, D.; Ningre, N.; Kontunen-Soppela, S.; Baldet, P.; Gibon, Y.; Dizengremel, P.; Vaultier, M.-N.; et al. Ozone affects ascorbate and glutathione biosynthesis as well as amino acid contents in three Euramerican poplar genotypes. Tree Physiol. 2014, 34, 253-266. [CrossRef] [PubMed]

44. Leuzinger, S.; Körner, C. Tree species diversity affects canopy leaf temperatures in a mature temperate forest. Agric. Forest Meteorol. 2007, 146, 29-37. [CrossRef]

45. Guenther, A.; Karl, T.; Harley, P.; Wiedinmyer, C.; Palmer, P.I.; Geron, C. Estimates of global terrestrial isoprene emissions using MEGAN (Model of Emissions of Gases and Aerosols from Nature). Atmos. Chem. Phys. 2006, 6, 3181-3210. [CrossRef]

46. Guenther, A.; Hewitt, C.N.; Erickson, D.; Fall, R.; Geron, C.; Graedel, T.; Harley, P.; Klinger, L.; Lerdau, M.; McKay, W.A.; et al. A global model of natural volatile organic compound emissions. J. Geophys. Res. Atmos. 1995, 100, 8873-8892. [CrossRef]

47. Joback, K.G.; Reid, R.C. Estimation of pure-component properties from group-contributions. Chem. Eng. Commun. 1987, 57, 233-243. [CrossRef]

48. Stein, S.E.; Brown, R.L. Estimation of normal boiling points from group contributions. J. Chem. Inf. Comp. Sci. 1994, 34, 581-587. [CrossRef]

49. Volz-Thomas, A.; Kolahgar, B. On the budget of hydroxyl radicals at Schauinsland during the Schauinsland Ozone Precursor Experiment (SLOPE96). J. Geophys. Res. 2000, 105, 1611-1622. [CrossRef]

50. Pätz, H.W.; Corsmeier, U.; Glaser, K.; Vogt, U.; Kalthoff, N.; Klemp, D.; Kolahgar, B.; Lerner, A.; Neininger, B.; Schmitz, T.; et al. Measurements of trace gases and photolysis frequencies during SLOPE96 and a coarse estimate of the local $\mathrm{OH}$ concentration from $\mathrm{HNO}_{3}$ formation. J. Geophys. Res. 2000, 105, 1563-1583. [CrossRef]

51. Klemp, D.; Kley, D.; Kramp, F.; Buers, H.J.; Pilwat, G.; Flocke, F.; Patz, H.W.; Volz-Thomas, A. Long-term measurements of light hydrocarbons $\left(\mathrm{C}_{2}-\mathrm{C}_{5}\right)$ at Schauinsland (Black Forest). J. Atmos. Chem. 1997, 28, 135-171. [CrossRef]

52. Kalthoff, N.; Corsmeier, U.; Volz-Thomas, A. Influence of valley winds on transport and dispersion of airborne pollutants in the Freiburg-Schauinsland area. J. Geophys. Res. 2000, 105, 1585-1597. [CrossRef]

53. Bonn, B.; Bourtsoukidis, E.; Sun, T.S.; Bingemer, H.; Rondo, L.; Javed, U.; Li, J.; Axinte, R.; Li, X.; Brauers, T.; et al. The link between atmospheric radicals and newly formed particles at a spruce forest site in Germany. Atmos. Chem. Phys. 2014, 14, 10823-10843. [CrossRef]

54. Duhl, T.R.; Helmig, D.; Guenther, A. Sesquiterpene emissions from vegetation: A review. Biogeosciences 2008, 5, 761-777. [CrossRef]

55. Aydin, Y.M.; Yaman, B.; Koca, H.; Dasdemir, O.; Kara, M.; Altinok, H.; Dumanoglu, Y.; Bayram, A.; Tolunay, D.; Odabasi, M.; et al. Biogenic volatile organic compound (BVOC) emissions from forested areas in Turkey: Determination of specific emission rates for thirty-one tree species. Sci. Total Environ. 2014, 490, 239-253. [CrossRef] [PubMed]

56. van Meeningen, Y.; Schurgers, G.; Rinnan, R.; Holst, T. BVOC emissions from English oak (Quercus robur) and European beech (Fagus sylvatica) along a latitudinal gradient. Biogeosciences 2016, 13, 6067-6080. [CrossRef]

57. Bonn, B.; von Schneidemesser, E.; Andrich, D.; Quedenau, J.; Gerwig, H.; Lüdecke, A.; Kura, J.; Pietsch, A.; Ehlers, C.; Klemp, D.; et al. BAERLIN2014-The influence of land surface types on and the horizontal heterogeneity of air pollutant levels in Berlin. Atmos. Chem. Phys. 2016, 16, 7785-7811. [CrossRef] 
58. Jacob, D.J. Introduction to Atmospheric Chemistry, 1st ed.; Princeton University Press: Princeton, NJ, USA, 1999; ISBN 13 978-0691001852.

59. Finlayson-Pitts, B.; Pitts, J. Chemistry of the Upper and Lower Atmosphere, 2nd ed.; Academic Press: Waltham, MA, USA, 1999; ISBN 978-0122570605.

60. Stocker, T.F.; Qin, D.; Plattner, G.-K.; Tignor, M.; Allen, S.K.; Boschung, J.; Nauels, A.; Xia, Y. (Eds.) IPCC: Climate Change 2013: The Physical Science Basis. Contribution of Working Group I to the Fifth Assessment Report of the Intergovernmental Panel on Climate Change; Cambridge University Press: Cambridge, UK; New York, NY, USA, 2013; ISBN 978-1-107-66182-0.

61. Churkina, G.; Kuik, F.; Bonn, B.; Lauer, A.; Grote, R.; Tomiak, K.; Butler, T.M. Effect of VOC Emissions from Vegetation on Air Quality in Berlin during a Heatwave. Environ. Sci. Technol. 2017, 51, 6120-6130. [CrossRef] [PubMed]

62. Curci, G.; Beekmann, M.; Vautard, R.; Smiatek, G.; Steinbrecher, R.; Theloke, J.; Friedrich, R. Modelling study of the impact of isoprene and terpene biogenic emissions on European ozone levels. Atmos. Environ. 2009, 43, 1444-1455. [CrossRef]

63. Anav, A.; de Marco, A.; Proietti, C.; Alessandi, A.; Dell'Aquila, A.; Cionni, I.; Friedlingstein, P.; Khvorostyanov, D.; Menut, L.; Paoletti, E.; et al. Comparing concentration-based (AOT40) and stomatal uptake (PODY) metrics for ozone risk assessment to European forests. Glob. Chang. Biol. 2016, 22, 1608-1622. [CrossRef] [PubMed]

64. De Marco, A.; Sicard, P.; Fares, S.; Tuovinen, J.P.; Anav, A.; Paoletti, E. Assessing the role of soil water limitation in determining the Phytotoxic Ozone Dose (PODY) thresholds. Atmos. Environ. 2016, 147, 88-97. [CrossRef]

65. Ormeno, E.; Mevy, J.P.; Vila, B.; Bousquet-Melou, A.; Greff, S.; Bonin, G.; Fernandez, C. Water deficit stress induces different monoterpene and sesquiterpene emission changes in Mediterranean species. Relationship between terpene emissions and plant water potential. Chemosphere 2007, 67, 276-284. [CrossRef] [PubMed]

66. Staudt, M.; Ennajah, A.; Florent Mouillot, F.; Joffre, R. Do volatile organic compound emissions of Tunisian cork oak populations originating from contrasting climatic conditions differ in their responses to summer drought? Can. J. For. Res. 2008, 38, 2965-2975. [CrossRef]

67. Šimpraga, M.; Verbeeck, H.; Demarcke, M.; Joó, É.; Pokorska, O.; Amelynck, C.; Schoon, N.; Dewulf, J.; Van Langenhove, H.; Heinesch, B.; et al. Clear link between drought stress, photosynthesis and biogenic volatile organic compounds in Fagus sylvatica L. Atmos. Environ. 2011, 45, 5254-5259. [CrossRef]

68. Llusià, J.; Peñuelas, J. Changes in terpene content and emission in potted Mediterranean woody plants under severe drought. Can. J. Bot. 1998, 76, 1366-1373. [CrossRef]

69. Peñuelas, J.; Filella, I.; Seco, R.; Llusià, J. Increase in isoprene and monoterpene emissions after re-watering of droughted Quercus ilex seedlings. Biol. Plant 2009, 53, 351-354. [CrossRef]

70. Nogués, I.; Medori, M.; Calfapietra, C. Limitations of monoterpene emissions and their antioxidant role in Cistus sp. under mild and severe treatments of drought and warming. Environ. Exp. Bot. 2015, 119, 76-86. [CrossRef]

71. Nogués, I.; Muzzini, V.; Loreto, F.; Bustamante, M.A. Drought and soil amendment effects on monoterpene emission in rosemary plants. Sci. Total Environ. 2015, 538, 768-778. [CrossRef] [PubMed]

72. Jud, W.; Vanzo, E.; Li, Z.; Ghirardo, A.; Zimmer, I.; Sharkey, T.D.; Hansel, A.; Schnitzler, J. Effects of heat and drought stress on post-illumination bursts of volatile organic compounds in isoprene-emitting and non-emitting poplar. Plant Cell Environ. 2016, 39, 1204-1215. [CrossRef] [PubMed]

73. Ochoa-Hueso, R.; Munzi, S.; Alonso, R.; Arróniz-Crespo, M.; Avila, A.; Bermejo, V.; Bobbink, R.; Branquinho, C.; Concostrina-Zubiri, L.; Cruz, C.; et al. Ecological impacts of atmospheric pollution and interactions with climate change in terrestrial ecosystems of the Mediterranean Basin: Current research and future directions. Environ. Pollut. 2017, 227, 194-206. [CrossRef] [PubMed]

(C) 2017 by the authors. Licensee MDPI, Basel, Switzerland. This article is an open access article distributed under the terms and conditions of the Creative Commons Attribution (CC BY) license (http:/ / creativecommons.org/licenses/by/4.0/). 